KATHRYN HOLLAND

\title{
THE LAW ON PSYCHOACTIVE SUBSTANCES IN NEW ZEALAND: THE END OF THE REGULATORY GAME OF CAT AND MOUSE
}

\author{
LLM RESEARCH PAPER
}

LAWS 513: LAW OF MEDICINE

FACULTY OF LAW

TE WHARE WÁNANGa O TE ŨPOKO O TE IKA A MĀUI

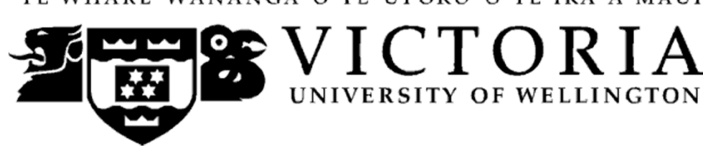

2013 


\section{Table of Contents}

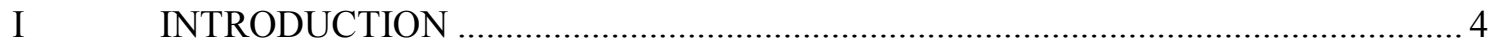

II THE SCOPE OF THIS PAPER …………………….......................................

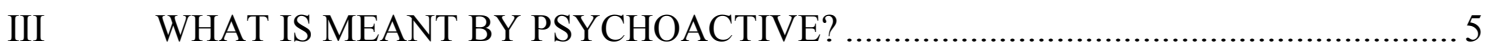

A The Meaning of Psychoactive Substance.................................................................. 6

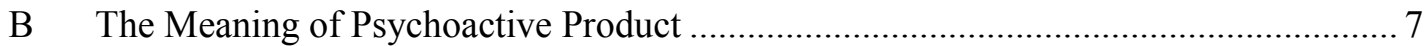

IV INTERNATIONAL OBLIGATIONS ……………..........................................

V DO PSYCHOACTIVE SUBSTANCES POSE A RISK OF HARM? .......................... 9

A Case Study: Massey University Study on Legal Party Pill use in New Zealand .......... 10

B Case Study: Gamma-hydroxybutyrate (GHB) ………………………………….... 10

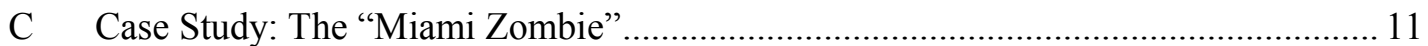

VI CAN STATE REGULATION OF PSYCHOACTIVE SUBSTANCES BE

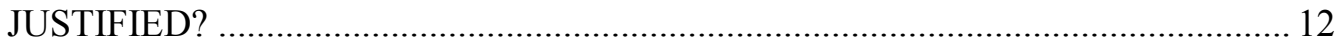

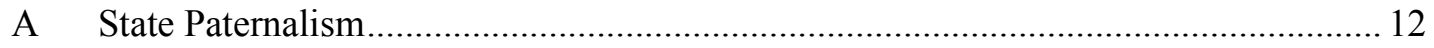

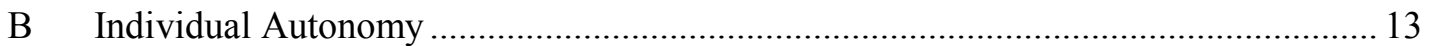

C Utilitarianism and the Wider Interests of Society ..................................................... 18

VII WAS THE MISUSE OF DRUGS ACT SUFFICIENT TO CONTROL THE USE OF PSYCHOACTIVE SUBSTANCES IN NEW ZEALAND? .................................... 21

A Temporary Class Drug Notice Mechanism................................................................... 21

VIII IS THE PSYCHOACTIVE SUBSTANCES ACT SUFFICIENT TO CONTROL AND MONITOR PSYCHOACTIVE SUBSTANCES IN NEW ZEALAND?............23

A What is the Scope of the Psychoactive Substances Act? ............................................... 24

B Are There Any Cultural Concerns that Arise as a Result of the Psychoactive Substances Act? ............................................................................................... 25

C Is the Requirement that all Individuals and Body Corporates must have Licences to Import, Manufacture, Research or Sell Psychoactive Substances Warranted?........ 29

D How can a Psychoactive Product Become an Approved Product? ............................... 33

E How Will the Authority Determine Whether a Psychoactive Product Poses Only a Low Risk of Harm? .............................................................................................. 36

F What Level of Evidence will be required by the Authority to determine whether a Psychoactive Product poses only a Low Risk of Harm?................................................ 40

G Where Can Psychoactive Products Be Sold or Supplied?............................................... 41

H How Can Psychoactive Products Be Advertised?......................................................... 43

I What are the Labelling Restrictions and Requirements for Psychoactive Products?... 45

J Should a Duty to Report Adverse Reactions Exist?................................................... 46

K Does the Ability for the Authority to Recall Approved Products provide a

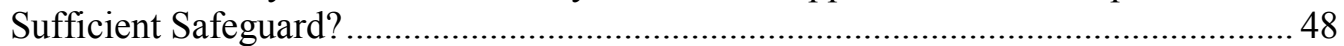

L Is the Appeal System Established under the Psychoactive Substances Act Adequate?

M How are the Restrictions and Prohibitions on the Importation, Manufacture and Sale of Psychoactive Products Enforced? ................................................................. 49

N Offences Relating to Psychoactive Substances that are not Approved Products .......... 50

O Should Personal Possession of a Psychoactive Substance be an Offence under the Psychoactive Substances Act? ............................................................................. 51

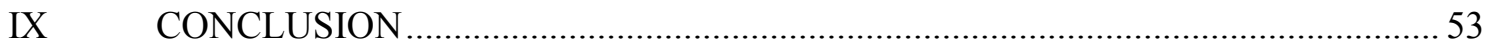




\section{Abstract}

This paper considers the recent global concern of psychoactive substance use alongside New Zealand's corresponding endeavour to regulate such substances under the Psychoactive Substances Act 2013. It establishes that psychoactive substances pose a risk of harm to individual consumers and to society in general. In light of this risk, it considers whether such harm justifies state intervention, whereby the autonomy of individuals would be limited for the safety of those individuals and the benefit of society. The theories of legal and political philosophers, including Immanuel Kant and John Stuart Mill, are considered to determine the philosophical basis for such regulation. This paper finds that such state paternalism, as found in the Psychoactive Substances Act, is justified. Having concluded that the Misuse of Drugs Act 1975 was insufficient to minimise the risk of harm caused by such substances, it argues in favour of the regulatory scheme established under the Psychoactive Substances Act. It concludes that the Psychoactive Substances Act is a revolutionary and innovative measure that will successfully minimise the harm caused, to individuals and society in general, by such substances.

\section{Word length}

The text of this paper (excluding abstract, table of contents, footnotes and bibliography) comprises approximately 15,032 words.

\section{Subjects and Topics}

Psychoactive Substances Act 2013

Substance Dependence

State Paternalism

Individual Autonomy 


\section{Introduction}

The Psychoactive Substances [Act] ends this dangerous game of cat and mouse by banning the import, the manufacture, the sale, the supply, and the possession of psychoactive substances. It reverses the onus of proof by making all psychoactive substances illegal, unless the industry can prove their products are low risk. ${ }^{1}$

Prior to the enactment of the Psychoactive Substances Act 2013 (PSA), the Misuse of Drugs Act 1975 (MoDA) allowed the government to classify and control psychoactive substances in New Zealand. Traditionally, the MoDA prohibited illicit substances recognised, by the New Zealand Government and international organisations, as those which pose a risk of harm to individual consumers and society. ${ }^{2}$ The conventionally narrow scope of the MoDA had previously allowed new psychoactive substances to infiltrate society and cause harm to individual consumers. These new psychoactive substances had, up until 17 July 2013, remained mostly unregulated. "This lack of regulation [meant a] lack of safety measures and controls." 3 Psychoactive substances were sold in New Zealand with very little, if any, consideration of their chemical composition, any associated health risks, or the age of the consumer. ${ }^{4}$ As a result, the Hon Peter Dunne MP put forward the PSA in an attempt to control the manufacture, importation, and sale of these substances in New Zealand. ${ }^{5}$

Part II clarifies the purpose and scope of this research paper on psychoactive substances. Part III then analyses the terminology used to describe psychoactive substances and products. Part IV identifies and discusses the international obligations that impose a duty on New Zealand to contribute towards reducing drug-related harm. Part V briefly identifies a number of harms and social problems that may result from the use of psychoactive substances by individuals. Part VI then provides an in-depth consideration of the applicability of the theories of state paternalism, individual autonomy, and utilitarianism. These theories are considered alongside the wider interests of society to determine whether regulation and, under some circumstances, prohibition of psychoactive

(9 April 2013) 689 NZPD 9133.

Misuse of Drugs Act 1975, s 3A.

New Zealand Drug Foundation "Submission to the Health Committee on the Psychoactive Substances Bill 2013" at [2].

$4 \quad$ Brook Sabin "Dairies becoming 'drug dealers', Parliament hears" 3 News (online ed, New Zealand, 8 May 2013) <http://www.3news.co.nz>.

$5 \quad$ United Future "Dunne: legal highs regime costs and penalties announced" (press release, 10 October 2012). 
substances can ever be justified. Part VII analyses the previous method of controlling psychoactive substances that were not scheduled as class A, B, or C drugs under the MoDA. It then concludes that the previous legislative procedure under the MoDA was insufficient to address the harms posed by unregulated and harmful psychoactive substances.

This paper then analyses, in Part VIII, the PSA to determine whether the new regulatory scheme will be sufficient to address the current problem caused by psychoactive substances in New Zealand. Having established that the PSA will allow substances that only pose a low risk of harm to be manufactured, imported, and sold, this paper asserts that the PSA will impose the bare minimum level of restrictions upon a person's individual autonomy. It is concluded that the recent reformation of the law on psychoactive substances was necessary and, for the most part, is sufficient to address the harms caused by such substances.

\section{The Scope of This Paper}

This paper is primarily concerned with psychoactive substances that are not currently controlled under the MoDA as class $\mathrm{A}, \mathrm{B}$, or $\mathrm{C}$ drugs. ${ }^{6}$ These substances, often known to society as legal highs ${ }^{7}$ or designer drugs, ${ }^{8}$ have the potential to mimic controlled substances and produce adverse effects. This paper addresses the potential harms caused by psychoactive substances and considers whether the PSA provides a suitable mechanism for controlling such substances in New Zealand. This paper also briefly considers substances that are controlled under the MoDA, as class A, B or C drugs, ${ }^{9}$ to demonstrate the harm that may be caused by dangerous psychoactive substances in general.

\section{What Is Meant by Psychoactive?}

The term "psychoactive" has been defined as that which is capable of "affecting the mind". 10 This definition is exceptionally broad and requires further analysis to determine

\footnotetext{
Misuse of Drugs Act, schs 1-3.

$7 \quad$ United Nations Office on Drugs and Crime 2013 World Drug Report Sales No. E.13.XI.6 (2013) at 63.

$8 \quad$ At 61 .

9 Misuse of Drugs Act, schs 1-3.

$10 \quad$ Ray Corsini The Dictionary of Psychology ( $1^{\text {st }}$ ed, Brunner Routledge, New York, 2002) at 778.
} 
what is meant by the terms "psychoactive substance" and "psychoactive product". The term "psychoactive" has been recognised as a synonym for "psychotropic".11 "Psychotropic drugs" are drugs that "produce mind-altering effects that may appear to be psychosis". " A "drug" is "a medicine or other substance which has a physiological effect when ingested or otherwise introduced into the body". 13 "Psychosis" is defined as: ${ }^{14}$

...a severe mental disorder of organic, psychological, functional cause, or the combination, that leads to bizarre mental states and behaviour. Signs may include confusion, delusions, hallucinations, incoherence, phobias, mood swings, mutism, [and] violence.

\section{A The Meaning of Psychoactive Substance}

The PSA, covered in further detail in Part VIII, provides a definition of the term "psychoactive substance". Section 9(2)(b) states that a psychoactive substance is "a substance, mixture, preparation, article, device, or thing that is capable of inducing a psychoactive effect (by any means) in an individual who uses the psychoactive substance." 15 Consequently, for "a substance, mixture, preparation, article, device or thing" to be regarded as a psychoactive substance, it must produce a "psychoactive effect". The term "psychoactive effect" is defined under the PSA as meaning "the effect of the substance on the individual's mind". 16

Ultimately, the Health Select Committee suggested that a narrow definition of the term "psychoactive substance" should be excluded from the PSA for two reasons. Firstly, although there was a risk that garden plants and low risk herbal products may be brought under the ambit of the PSA, a narrow definition should be excluded to "avoid leaving loopholes". ${ }^{17}$ Secondly, the PSA also grants the Governor-General the ability to declare substances not to be psychoactive for the purposes of the Act. ${ }^{18}$ It is expected that this

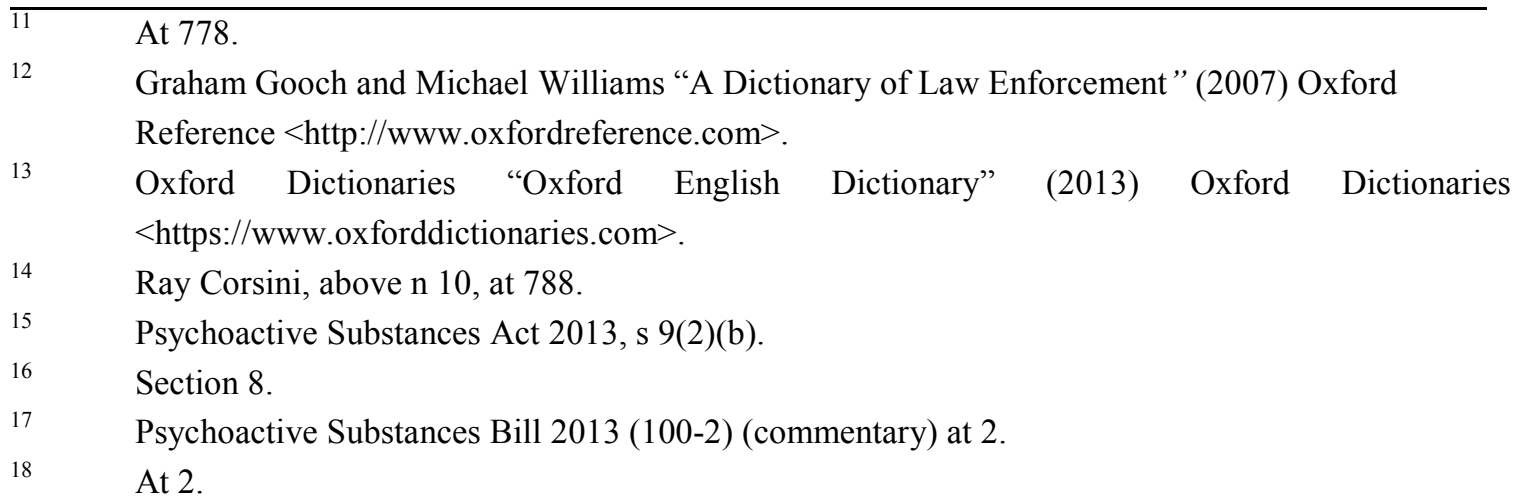


will alleviate most concerns about minor psychoactive substances being captured under the PSA. ${ }^{19}$

Furthermore, s 9(3) offers some protection to substances that are regulated elsewhere. ${ }^{20}$ These excluded substances include controlled drugs, medicines, food, herbal remedies, dietary supplements, alcohol, tobacco, and other substances declared by the GovernorGeneral not to be psychoactive substances for the purposes of the Act. ${ }^{21}$ It is necessary to exclude such substances from the ambit of the PSA to prevent an unclear system where one substance may be covered under different, and potentially inconsistent, pieces of legislation.

\section{B The Meaning of Psychoactive Product}

Section 8 of the PSA determines that a "psychoactive product or product means a finished product packaged and ready for retail sale that is a psychoactive substance or contains 1 or more psychoactive substances". ${ }^{22}$ As a result, any product ready for retail sale, which contains a psychoactive substance, will have to adhere to the provisions under the PSA before it can be sold to consumers. ${ }^{23}$

\section{International Obligations}

The issue of the manufacture, importation, sale, and use of illicit drugs and psychoactive substances is not limited to New Zealand. "New Zealand has ratified three United Nations drug conventions that require New Zealand to make the cultivation, distribution, and possession of drugs listed in the conventions ... a criminal offence." ${ }^{24}$ To assist nation states with meeting their obligations, the International Narcotics Control Board ${ }^{25}$

\footnotetext{
(9 July 2013) 692 NZPD 11777.

$20 \quad$ Psychoactive Substances Act, s 9(3).

21 Section 9(3).

$22 \quad$ Section 8.

23 Section 33

24 Ministry of Health Regulatory Impact Statement: New Regulatory Regime for Psychoactive Substances (1 July 2012) at 19; See generally - Single Convention on Narcotic Drugs of 1961529 UNTS 151 (opened for signature 24 January 1961, entered into force 13 December 1964); United Nations Convention against Illicit Traffic in Narcotic Drugs and Psychotropic Substances 1582 UNTS 95 (opened for signature 20 December 1988, entered into force 11 November 1990). Convention on Psychotropic Substances 19711019 UNTS 175 (opened for signature 11 January 1971, entered into force 16 August 1976).

25 Single Convention on Narcotic Drugs of 1961, art 9.
} 
has published the names of illicit substances that must be controlled under domestic law. ${ }^{26}$ New Zealand has previously met these obligations by prohibiting the listed substances under the MoDA. ${ }^{27}$ However, it has now become uncertain as to whether this method of prohibition is sufficient to confront the new global problem caused by harmful psychoactive substances.

The United Nations Office on Drugs and Crime has recognised: ${ }^{28}$

... scheduling or controlling a substance is a lengthy - and costly - process, especially as it is the authorities who bear the onus of proof. Additionally, controlling an ever-larger number of substances, affecting police, customs, forensic laboratories, import/export authorities and the health authorities, among others, may stretch some Member States beyond their capacities.

Prior to the PSA, the onus was on the state to prove that a psychoactive substance posed a risk of harm. Consequently, the responsibility of funding research on psychoactive substances to determine their level of risk also rested on the state. ${ }^{29}$

During the second reading of the PSA, Mr Dunne stated: ${ }^{30}$

...if this legislation is, as I believe it will be, successful, then we can expect to see that model picked up and implemented right around the world, because this issue is not one just for this country; it is one that is affecting every jurisdiction.

It is apparent that the use of harmful psychoactive substances is a global issue. Mr Dunne also informed Parliament that, during the 2013 United Nations Office on Drugs and

\footnotetext{
26 International Narcotics Control Board List of Psychotropic Substances under International

Control: In accordance with the Convention on Psychotropic Substances of 1971 (24th ed, May 2010); International Narcotics Control Board Red List: List of Precursors and Chemicals Frequently used in the Illicit Manufacture of Narcotic Drugs and Psychotropic Substances under International Control: In accordance with the United Nations Convention against Illicit Traffic in Narcotic Drugs and Psychotropic Substances 1988 (13th ed, January 2012); International Narcotics Control Board Yellow List: List of Narcotic Drugs under International Control: In accordance with the Single Convention on Narcotic Drugs 1961 (51st ed, December 2012).

$27 \quad$ Misuse of Drugs Act 1975, s 3A; Schedules 1-5.

$28 \quad$ United Nations Office on Drugs and Crime, above $\mathrm{n} 7$, at xiii.

$29 \quad$ (2 July 2013) 691 NZPD 11577.

$30 \quad$ (27 June 2013) 691 NZPD 11395.
} 
Crime meeting, other nations were considering New Zealand's then proposed legislative change with great interest. ${ }^{31}$

Furthermore, in 2013, the Commission on Narcotic Drugs passed a resolution that requires all member states to collect and share information about new psychoactive substances. ${ }^{32}$ The PSA will assist New Zealand with meeting this obligation as it permits the sharing of information, gathered for the purposes of regulation, with the World Health Organization and fellow World Trade Organization countries. ${ }^{33}$ This will allow New Zealand to provide information, gathered from preclinical and clinical trials paid for by manufacturers and importers of psychoactive substances, to other member states.

\section{$V$ Do Psychoactive Substances Pose a Risk of Harm?}

Having established that New Zealand is under an obligation to reduce drug-related harm, this paper now determines whether psychoactive substances are able to cause harm to individual consumers and society in general. The New Zealand Drug Foundation (NZDF) has a national focus of minimising drug related harm. ${ }^{34}$ In its submission to the Health Select Committee on the PSA, the NZDF outlined a selection of harms that may be caused by psychoactive substances: ${ }^{35}$

...harms to individuals and families include injury, disease, social, personal and financial problems and a reduced quality of life. Harms to societies include unsafe communities, increased need for law enforcement, and high health and economic costs.

The NZDF also submitted that recent reports have indicated psychoactive substances may have severe detrimental effects on the physiological and psychological health of individual consumers. "[These] reported harms are wide ranging and include agitation and paranoia through to psychosis, kidney-failure, limb loss and even death". ${ }^{36}$

\footnotetext{
(9 April 2013), 689 NZPD 9134.

32 The Commission on Narcotic Drugs Promoting the sharing of expertise in and knowledge on forensic drug profiling GA Res 56/5, E/2013/28 (2013).

33 Psychoactive Substances Act, s 36(3)(a).

34 New Zealand Drug Foundation, above n 3, at [8].

$35 \quad$ At [8].

36 At [2].
} 


\section{A Case Study: Massey University Study on Legal Party Pill use in New Zealand}

"[This] survey consisted of a random national household sample of 2,010 people aged 1345 years old". ${ }^{37}$ Out of the results obtained, it was reported that 50.4 per cent experienced trouble sleeping, 18.4 per cent experienced a loss of energy, 15.6 per cent experienced strange thoughts, 14.8 per cent experienced mood swings and 8.4 per cent experienced paranoia. The survey also recorded significant physical harms caused by the use of legal party pills. The physical problems most often experienced from the use of legal party pills included "poor appetite, hot/cold flushes, heavy sweating, stomach pains/nausea, headaches, and tremors and shakes". ${ }^{38}$ The results from this study demonstrate that the harms caused by psychoactive substances are wide ranging and have the potential to be different for each individual consumer.

\section{B Case Study: Gamma-hydroxybutyrate (GHB)}

...between 2000, when [GHB] was assessed by the EACD [Expert Advisory Committee on Drugs] and its eventual scheduling in the Act in 2002, Auckland Hospital reported over thirty admissions and one death associated with GHB misuse. ${ }^{39}$

Research published in the American Journal of Emergency Medicine in 2011 determined that out of the "226 deaths included 213 had cardiorespiratory arrest and 13 had fatal accidents". ${ }^{40}$ The study also provided an example of a label found on a psychoactive product that contained the psychoactive substance GHB: ${ }^{41}$

Excessive doses may result in sweating, muscle spasms, vomiting, bedwetting, and diarrhoea. Unless drugs or alcohol have been taken with ZEN, the only treatment necessary is to SLEEP IT OFF! A call for help may result in uninformed emergency medical personnel using expensive, unnecessary, and potentially dangerous methods of arousal.

37

C Wilkins and others Legal party pill use in New Zealand: Prevalence of use, availability, health harms and 'gateway effects' of benzylpiperazine (BZP) and trifluoromethylphenylpiperazine (TFMPP) (Centre for Social and Health Outcomes Research and Evaluation, Auckland, 2006) at 5. At 32 .

Ministry of Health Regulatory Impact Statement, above n 24, at 23; See also - Expert Advisory Committee on Drugs The Expert Advisory Committee on Drugs' (EACD) advice on: GammaHydroxybutyric Acid and Related Substances ('Fantasy') (December 2001).

Deborah L. Zvosec and Others "Case Series of 226 y-hydroxybutyrate - Associated Deaths: Lethal Toxicity and Trauma” (2011) 29(3) American Journal of Emergency Medicine 319 at 319. At 320 . 
This dangerous fiction created by the psychoactive substances industry is of particular concern when one considers the findings of the study in relation to bystanders: ${ }^{42}$

... of 102 cases with known symptoms before death, 30 were victims left "sleeping" or "snoring" by witnesses and later found in arrest or dead. Seventy-two others had witnessed adverse effects (agitation, vomiting, seizures, loss of consciousness); for 66 of these, activation of emergency medical services was delayed until the victim was found in arrest or dead.

These statistics demonstrate that there is often an unhealthy and undesirable competition between the psychoactive substances industry and governments. Manufacturers and importers have an interest in encouraging consumers to use their products, whereas the government of a nation maintains an interest in keeping individuals and society safe from harm. $^{43}$

\section{Case Study: The "Miami Zombie"}

In May 2012, Rudy Eugene, who was presumed to be under the influence of psychoactive substances, was shot by Miami police after he chewed off 75 per cent of a man's face. ${ }^{44}$ The toxicology report held that no psychoactive substances were detected in his system at the time of his death; however, the adequacy of such testing regimes is uncertain. After the toxicology report was released, Dr Barry Logan acknowledged that "there are hundreds of bath salt compounds out there, but toxicologists can only test for 40". Even after the report came back clear, experts reported that "there is no question Eugene's behaviour was drug-induced - and not by marijuana. But [it is] hard to prove because even the most sophisticated labs cannot test for every compound". 46

Since their creation, this particular class of psychoactive substances has been proven to inflict extremely detrimental effects on individual consumers: ${ }^{47}$

\footnotetext{
At 323 .

43 Peter Dunne "Dunne: legal highs regime costs and penalties announced" (press release, 10 October 2012).

$44 \quad$ Andrew Moran "Bath Salts - Inside the rise of latest drug to capture notoriety" (30 May 2012) Digital Journal <http://www.digitaljournal.com>.

45 Susannah Bryan "Even experts question claim that Rudy Eugene was not on bath salts" (6 July 2012) Sun Senteniel <http://www.sun-senteniel.com>.

46 Susannah Bryan, above $\mathrm{n} 45$.

$47 \quad$ Andrew Moran, above $n 44$.
} 
Bath salts are composed of MDPV, mephedrone and pyrovalerone and because of its chemical composition it can establish short- and long-term effects for the users. Individuals who consume bath salts desire a euphoric feeling that can also increase energy, arousal, sociability and motivation. However, the actual results are frightening as bath salts can lead to suicidal thoughts, paranoia, psychotic delusions and violent behaviour.

The incident involving Mr Eugene occurred months after one of the most commonly used compounds in the manufacturing of bath salts, Methylenedioxypyrovalerone (MDPV), was classified as dangerous by the American National Institute on Drug Abuse. ${ }^{48}$ In New Zealand, MDPV is classified as an illegal substance because it is an analogue substance of the Class B controlled drug Pyrovalerone. ${ }^{49}$

Having established that psychoactive substances have the ability to cause great harm to individuals and society, it would be unreasonable to allow psychoactive substances to be manufactured, imported, or sold in a manner that is unsafe. Instead, this paper concludes that it is necessary to consider what safeguards could, and should, be implemented to reduce this risk of harm.

\section{Can State Regulation of Psychoactive Substances be justified?}

Various legal and political philosophers have considered whether the state is justified in intervening with the actions of an individual. Three influential and compelling theories used to answer this question include the concept of paternalism by the state, the notion of individual autonomy, and the consequentialist theory of utilitarianism.

\section{A State Paternalism}

The concept of paternalism can be divided into two categories. Pure paternalism occurs when "the class of persons whose freedom is restricted is identical with the class of persons whose benefit is to be promoted by such restrictions". ${ }^{50}$ Impure paternalism

\footnotetext{
N8 Nora Volkow "Bath Salts: Emerging and Dangerous Products" (February 2011) National Institute on Drug Abuse <http://www.drugabuse.gov>.

49 Misuse of Drugs Act, sch 1(2)(1); Nicholas Jones "Police warn on tainted E pills" The New Zealand Herald (Online ed, New Zealand, 28 September 2011) <http://www.nzherald.co.nz>. $50 \quad$ Gerald Dworkin "Paternalism" (1970) in J Feinberg and H Gross (ed) Philosophy of Law, $4^{\text {th }}$ ed, (1991) 258 at 260.
} 
occurs when the class of persons whose freedom is restricted is not identical with the class of persons whose benefit is to be promoted by such restrictions. ${ }^{51}$ The PSA contains instances of both pure and impure paternalism. The Act places restrictions on the autonomy of individual consumers and the psychoactive substances industry to protect the health and safety of individual consumers.

\section{Gerald Dworkin proposed: ${ }^{52}$}

... it may be that impure paternalism requires arguments or reasons of a stronger kind in order to be justified, since there are persons who are losing a portion of their liberty and they do not even have the solace of having it be done "in their own interest".

He advocated that this may be the case especially where the victim can avoid the harm as the "incurring of the harm requires, so to speak, the active cooperation of the victim". 53 Under this analysis, individual consumers of psychoactive substances do actively decide to use them. Consequently, the paternalistic nature of the PSA, which restricts the freedom of the psychoactive substances industry, may be harder, albeit not impossible, to justify. Such state paternalism can, in reality, be justified by reference to the theories of individual autonomy and utilitarianism.

\section{B Individual Autonomy}

Immanuel Kant declared that an individual can only make autonomous decisions when his or her choices are consistent with the categorical imperatives. ${ }^{54}$ A categorical imperative is defined as a "requirement that binds anybody, regardless of their inclinations". 55 One example of a categorical imperative is Kant's "formula of universal law, [that one should] 'act only on that maxim through which you can at the same time will that it should become universal law", 56 Individuals are only permitted to act

\footnotetext{
At 260 .

$52 \quad$ At 260 .

$53 \quad$ At 260 .

$54 \quad$ Immanuel Kant Metaphysik der Sitten Paul Natorp (ed) (Reimer, Berlin, 1907) (translated ed:

Mary Gregor (Translator) Immanuel Kant The Metaphysics of Morals (Cambridge University Press, Cambridge, 1991) at 51).

55 Simon Blackburn "The Oxford Dictionary of Philosophy" (2013) Oxford Reference $<$ http://www.oxfordreference.com>.

56 Simon Blackburn, above n 55.
} 
autonomously when the choices they make are morally capable of becoming universal laws: ${ }^{57}$

... any action is right if it can coexist with everyone's freedom in accordance with a universal law, or if on its own maxim the freedom of choice of each can coexist with the freedoms of everyone in accordance with a universal law.

It would be an impractical universal law to allow everyone to consume high risk psychoactive substances that may cause significant harm to their individual health or to society in general. Kant also requires that for an individual's autonomy to be respected,

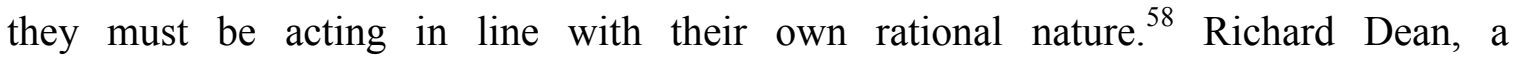
contemporary philosopher, acknowledged that under Kant's moral theory, a way to: ${ }^{59}$

... sacrifice one's own rational nature is to destroy oneself or one's minimal rational nature altogether. This kind of sacrifice - [such as] taking permanently mind-altering drugs or the like - is probably what most naturally comes to mind when one thinks of sacrificing one's rational nature.

This proposition suggests that individuals who are prepared to accept the risk of permanent mental degradation by consuming harmful substances are acting in a manner that is inconsistent with their own rational nature.

John Stuart Mill, a great supporter of liberalism and utilitarianism, also considered the extent of an individual's right to autonomy. He asserted that: ${ }^{60}$

...neither one person, nor any number of persons, is warranted in saying to another human creature of ripe years, that he shall not do with his life for his own benefit what he chooses to do with it.

Mill argued that "with respect to his own feelings and circumstances, the most ordinary man or woman has means of knowledge immeasurably surpassing those that can be possessed by anyone else". ${ }^{61}$ Nevertheless, Mill also limited the right of individual autonomy: ${ }^{62}$

\begin{tabular}{ll}
\hline 57 & Immanuel Kant, above n 54, at 56. \\
58 & At 106. \\
59 & Richard Dean “The Formula of Humanity as an End in Itself” Thomas Hill (ed) The Blackwell \\
& Guide to Kant's Ethics (Blackwell Publishing Ltd, Oxford, 2009) 83 at 92. \\
60 & John Stuart Mill On Liberty (2 ${ }^{\text {nd }}$ ed, John W Parker and Son, London, 1859) at 136. \\
61 & At 137.
\end{tabular}


... to human beings in the maturity of their faculties. We are not speaking of children, or of young persons below the age which the law may fix as that of manhood or womanhood. Those who are still in a state to require being taken care of by others, must be protected against their own actions as well as external injury.

Contemporary philosophers, Tom Beauchamp and James Childress have defined autonomy as "self-rule that is free from both controlling interference by others and from limitations, such as inadequate understanding that prevent meaningful choice". ${ }^{63}$ This proposition, that an individual needs to possess an adequate understanding of their choices before they can make an autonomous decision, holds merit. It is apparent that some individual consumers would not have used psychoactive substances if they fully comprehended the harms that such substances may inflict. ${ }^{64}$

Rebecca Walker also considered the notion of "rational autonomy". 65 Under this conception, if an individual is aware that a substance causes harm to individual health, and yet, he or she consumes that substance on the basis that they did not believe it would cause them harm, that individual would be acting irrationally. It may be that the individual possesses all the relevant information, and yet at the same time, does not adequately understand that information.

The PSA, considered in Part VIII of this paper, is inherently paternalistic and imposes significant restrictions on individual autonomy. The purpose of the PSA refers only to protecting the health and safety of individuals rather than for the benefit of society in general. ${ }^{66}$ Whilst the PSA is able to be justified under the Kantian theory, it can generally be perceived as in conflict with Mill's theory of individual autonomy and liberty unless further consideration is given.

1 Does the existence of substance dependence interfere with an individual's autonomy?

62 At 22-23.

63 Tom Beauchamp and James Childress Principles of Bioethics $\left(6^{\text {th }}\right.$ ed, Oxford University Press, New York, 2009) at 99.

64 Rebecca Ryan, “Teen's horrific tangle with legal highs” The New Zealand Herald (online ed, Oamaru, 19 July 2013) <http://www.nzherald.co.nz>.

65 Rebecca Walker "Respect for Rational Autonomy" (2009) 19(4) Kennedy Institute of Ethics Journal 339 at 340.

66 Psychoactive Substances Act, s 3. 
Robert Goodin considered "whether, in the case of smoking, the active cooperation of the smoker really is such as to constitute voluntary acceptance of the consequent risks of illness and death". ${ }^{67} \mathrm{He}$ asserted that "obviously, people cannot voluntarily accept the health risks of smoking if they do not know what they are". ${ }^{68}$ Furthermore, even in the situation where an individual understood the potential risks to his or her health, informed consent could be inadequate because of substance dependence. ${ }^{69}$ For example, in the United States, up to 95 per cent of adults addicted to cigarettes "are thought to have been addicted before coming of age" ${ }^{70}$ This is referred to as the "crux of the matter" whereby: ${ }^{71}$

...being below the age of consent when they first began smoking, smokers were incapable of meaningfully consenting to the risks in the first instance. Being addicted by the time they reached the age of consent, they were incapable of consenting later, either.

Goodin permits state paternalism and limits individual autonomy on the grounds that smoking may have a disproportionate effect on vulnerable individuals and result in substance dependence.

Substance dependence has been defined as "a compelling urge for and psychological dependence on an addictive substance to the degree that acquiring and using the substance becomes a priority in the person's life". ${ }^{72}$ The New Zealand Addiction Research Centre has claimed that "all mood-altering substances have the potential to form addictions". 73 Many psychoactive substances currently, and will in the future, come under this scope. Experts in various fields have advocated that the addiction an individual suffers to a substance may remove that individual's ability to exercise their autonomy. ${ }^{74}$

\footnotetext{
67 Robert E Goodin No Smoking: The Ethical Issues (University of Chicago Press, Chicago, 1989) at 16.

At 20.

At 25 .

At 30 .

At 30 .

Andrew M Colman Oxford Dictionary of Psychology (Oxford University Press, New York, 2001) at 958 .

73 Centre for Addiction Research "Submission to the Health Committee on the Psychoactive Substances Bill 2013” at [2].

74 Frank Koopmans and Srdjan Sremac "Addiction and Autonomy: are Addicts Autonomous" (2011) 9 Nova Prisutnost 171 at 179.
} 
According to Harry Frankfurt: ${ }^{75}$

... addicts are not free because they have a first order desire to take heroin but a second order desire not to desire to take heroin... freedom of the will occurs when our first order desires are in line with our second order desires: we do what we desire to desire to do.

It therefore follows that if an individual has: ${ }^{76}$

...lost the power of self-control, it would seem that he/she cannot be held responsible in the absence of that power. And that would mean that such a person should be protected from such a state, i.e. by restrictions on certain drugs.

In recent years, there have been reports of situations where individuals under the influence of psychoactive substances have engaged in socially unacceptable activities to fund their habit. In 2011, a 15-year-old young man from Oamaru became a victim of substance dependence to unregulated psychoactive substances. ${ }^{77}$ Eventually, with assistance from his mother, the young man spent nine weeks in a psychiatric hospital to recover from his addiction to psychoactive substances. This case study establishes that the use of certain psychoactive substances may also result in substance dependence. Because of the aforementioned similarities which exist between psychoactive substances and cigarettes, it is logical that Goodin's argument would also apply to the use of psychoactive products.

This paper proposes that the restriction on individual autonomy that arises as a result of the PSA is justifiable. It is logical to control substances that may, when consumed by an individual, result in harm or substance dependence. Harms are caused by, and inflicted upon, individual consumers who are desperate to fund their habit. ${ }^{78}$ Prohibitions and controls over certain substances will have the potential to minimise the risk of addiction to psychoactive substances by determining which substances pose a medium or high risk of future addiction. ${ }^{79}$

\footnotetext{
Frank Koopmans and Srdjan Sremac, above 74, at 179.

$76 \quad$ At 182 .

$77 \quad$ Rebecca Ryan, above n 64.

78 Rebecca Ryan, above n 64.

79 Psychoactive Substances Act, s 11(3)(d).
} 


\section{Utilitarianism and the Wider Interests of Society}

\section{The utilitarian perspective}

Jeremy Bentham advocated the theory of utilitarianism. He focussed on the overall utility of an act or law and acknowledged that: ${ }^{80}$

... every law is an evil, for every law is an infraction of liberty. Government... has but the choice of evils. In making that choice, what ought to be the object of the legislator? He ought to be certain of two things: $1^{\text {st }}$, that in every case the acts which he undertakes to prevent are really evils; and, $2^{\text {nd }}$, that these evils are greater than those which he employs to prevent them.

A law is only justified if it addresses the issue of a greater evil within society. If a law causes more harm to society than it does well, then it cannot be perceived as promoting the best interests of society in general.

John Stuart Mill also established the harm principle, whereby "the only purpose for which power can be rightfully exercised over any member of a civilised community, against his will, is to prevent harm to others". ${ }^{81}$ For the legal regulation of psychoactive substances to be legitimate, it is not enough that it causes harm to the health of the individual consumer, it must instead cause harm to other members within society.

\section{The Māori perspective}

New Zealand society is diverse and consists of different cultural groups including Māori and Pākehā. As acknowledged by Grant Berghan: ${ }^{82}$

... one of the key differences between Māori and non-Māori (pākeha/western) society is the Māori emphasis on the well-being of the group, as opposed to the western focus on the individual.

$80 \quad$ Étienne Dumont (ed) Jeremy Bentham Traités de législation, civile et pénale (1st ed, Bossange, Père et Fils, Paris, 1820) (translated ed: R Hildreth (translator) Jeremy Bentham Theory of Legislation ( $2^{\text {nd }}$ ed, Trübner, London, 1871) at 66).

81 John Stuart Mill, above n 60, at 22.

82 Grant Berghan "Māori point of view" Health Promotion Forum of New Zealand (March 2007)

$<$ http://www.hauora.co.nz>. 
Māori have a traditionally strong collective identity, whereby decisions are often made by the whānāu, hapū and iwi: ${ }^{83}$

...whānau members will feel strongly that they share in the achievements of their kin, and the whānau may even make decisions for a member, usually in consultation with the person concerned.

The Ministry of Health has acknowledged that under the: ${ }^{84}$

... traditional Māori approach, the inclusion of the wairua [the spiritual health], the role of the whānāu (family) and the balance of the hinengaro (mind) are as important as the physical manifestations of illnesses.

If a Māori individual uses substances which cause an imbalance in their wairua it may also have an impact on the overall health of their whānāu, hapū and iwi collectively. Therefore, it is also necessary to consider the potential harm caused not only to individual consumers, but also to their whānāus, hapūs and iwis.

\section{The fiscal costs of psychoactive substance use within New Zealand}

The clinical director of the Waikato Hospital Emergency Department, Dr John Bonning, reported that there was: ${ }^{85}$

... a considerable increase in recent visits to hospital emergency departments nationwide, [prior to the enactment of the PSA], by people experimenting with synthetic drug K2 [that was] holding up the treatment of worthy emergency cases.

This demonstrates that hospitals were, prior to the PSA, becoming inundated with individual consumers of psychoactive substances who had suffered adverse reactions.

Furthermore, the Business and Economic Research Ltd (BERL) report produced for the Ministry of Health also reported that drug-related costs, excluding alcohol, under the

83 Mauri Ora Associates "Best health outcomes for Māori: Practice implications" (December 2008) Medical Council of New Zealand <http://www.mcnz.org.nz>.

84 Mason Durie “Te Whare Tapa Whā” (1985) Ministry of Health <http://www.health.govt.nz>.

85 Danielle Nicholson "K2 Victims Clog Hospital EDs" Hamilton News (Hamilton, 21 June 2013) at 1. 
criminal sector in $2005 / 2006$ amounted to $\$ 394,900,000 .{ }^{86}$ These statistics determine that scheduling and controlling harmful drugs in New Zealand requires significant financial expenditure from society. As this paper has already established, psychoactive substances have the potential to cause harm similar to that caused by substances prohibited under the MoDA. Consequently, it is apparent that these psychoactive substances may also impose large financial costs on the government and society.

The BERL report also established that $\$ 129,700,000$ of the total drug-related cost in $2005 / 2006$ was used to imprison individuals for drug-related offences. ${ }^{87}$ This indicates that if all psychoactive substances were controlled under the MoDA as illicit substances, the cost to the taxpayer of maintaining the justice sector would increase. Considering it is estimated that certain psychoactive substances pose only a low risk of harm to individual consumers and society, making individual possession of a psychoactive substance an offence which carried a prison term would be excessive. It is important that the legal ramifications for individual possession of psychoactive substances are reasonable and, at the same time, are able to act as a deterrent. The PSA, analysed further in Part VIII of this paper, successfully provides a good balance whereby individual possession is met by reasonable monetary fines rather than imprisonment.

\section{The non-fiscal harms resulting from the use of psychoactive substances}

The New Zealand Nurses Association has submitted "that nurses observe and are also harmed from aggressive and psychotic behaviours induced by party pills similar to those caused by banned Class A and Class B drugs". ${ }^{88}$ This shows that medical professionals, who are treating individuals suffering from adverse reactions to psychoactive substances, are also at risk of being harmed. The New Zealand Police Association (NZPA) also submitted that there was: ${ }^{89}$

... a clear link between an increase in addiction to legal highs and an increase in crime aggravated robbery and theft of legal highs from dairies and other retail outlets as people steal to fuel their addiction.

\footnotetext{
86 Business and Economic Research Ltd "Costs of Harmful Alcohol and Other Drug Use” (March 2009) at 69.

$87 \quad$ At 65.

88 New Zealand Nurses Association "Submission to the Health Committee on the Psychoactive Substances Bill 2013" at [5].

89 New Zealand Police Association "Submission to the Health Committee on the Psychoactive Substances Bill 2013" at [3].
} 
This is consistent with the assertion from the 15-year-old young man from Oamaru, mentioned above, who reported that, at the crux of his addiction to psychoactive substances, he spent around $\$ 200$ a day on those substances and broke into over 300 cars to steal the possessions inside to fund his habit. ${ }^{90}$ The NZPA also reported an "increase in violent episodes and domestic violence attributed to legal highs". 91

It is evident that the use of psychoactive substances by individuals may also cause harm to society in general. The PSA creates a regulatory scheme that aims to prevent the dangerous consumption of psychoactive products by individuals. Such regulation will reduce the level of criminal activity executed by individuals under the influence of such substances. Furthermore, the Act will also minimise the costs attributed to providing healthcare to individuals who suffer adverse reactions to harmful psychoactive substances.

\section{Was the Misuse of Drugs Act Sufficient to Control the use of Psychoactive Substances in New Zealand?}

The MoDA establishes whether a substance is illegal under New Zealand law and, if so, what the penalties are for manufacturing, selling, or using the controlled substance. In 2011, the Law Commission released a report on the MoDA. This report confirmed that the lack of a regulatory regime for psychoactive substances that came outside the scope of the MoDA was problematic. It identified that: ${ }^{92}$

...new psychoactive substances can be manufactured, imported and sold without restriction until they are proven to be harmful and scheduled either as restricted substances or controlled drugs...there is in practice a significant time lapse between when new substances start to become available for use and when authorities have gathered sufficient evidence on patterns of use and their effects to determine whether they should be scheduled and regulated or prohibited.

\section{A Temporary Class Drug Notice Mechanism}

\footnotetext{
$90 \quad$ Rebecca Ryan, above n 64.

$91 \quad$ New Zealand Police Association, above n 89, at [3].

92 Law Commission Controlling and Regulating Drugs: A Review of the Misuse of Drugs Act 1975

(NZLC R122, 2011) at 25-26.
} 
In August 2011, Parliament amended the MoDA to allow the Minister of Health (the Minister) to issue Temporary Class Drug Notices (TCDN). ${ }^{93}$ This mechanism allowed the Minister to "prohibit for a 12-month period, ${ }^{94}$ the importation, manufacture, sale and supply of substances listed by a notice in the Gazette". ${ }^{95}$ Substances that were subject to TCDNs were to be treated the same as Class C drugs under the MoDA. ${ }^{96}$

1 The onus to prove a substance poses, or may pose, a risk of harm

Under the TCDN mechanism, the onus was on the Minister to prove that a substance posed, or may have posed, a risk of harm. Section 4(3) stated that: ${ }^{97}$

... the Minister must not give notice under subsection (1) unless he or she is satisfied that the substance, preparation, mixture, or article that is to be specified in the notice poses, or may pose, a risk of harm to individuals, or to society.

This provision allowed harmful psychoactive substances to be sold to the public until the Minister was able to gather enough evidence to satisfy this requirement.

\section{Time constraints}

TCDNs could only come into effect seven days after they had been published in the gazette. ${ }^{98}$ This provision existed to provide manufacturers, importers, and retailers notice that they were required to remove products that contained the listed substances from their premises. However, in reality, it also provided manufacturers, importers and retailers an extra week in which they could offload harmful products onto the public.

The 12-month duration of a TCDN was also unsatisfactory. ${ }^{99}$ The process of gathering all the necessary information required to determine whether or not a product would pose a risk of harm was often time consuming. For example, the substance GHB was available for two years before the government was able to classify it as a controlled substance. ${ }^{100}$

\footnotetext{
Misuse of Drugs Act, s 4C.

$94 \quad$ Section $4 \mathrm{E}(1)(\mathrm{a})$.

95 Ministry of Health Regulatory Impact Statement, above n 24, at 19; Misuse of Drugs Act, s 4C(1).

$96 \quad$ Misuse of Drugs Act, s 4D.

97 Section $4 \mathrm{C}(3)$.

98 Section $4 \mathrm{C}(6)$.

99 Section $4 \mathrm{E}(2)$.

100 Ministry of Health Regulatory Impact Statement, above n 24, at 23.
} 


\section{Analogous substances}

The TCDN mechanism stated "a substance that has a structure substantially similar to a temporary class drug [was] not to be treated as a controlled drug analogue by reason only of that similarity" ${ }^{101}$ This created a situation in which manufacturers were able to make minor alterations to the chemical composition of a substance so that it could be sold again. ${ }^{102}$ However, the Law Commission previously recognised that "it is unsatisfactory to have the choice of regulatory approach for substances determined by such artefactual distinctions in chemical structure". ${ }^{103}$ This is because: ${ }^{104}$

... the focus on chemical structure does not take into account the extent to which analogue substances have the same or a similar impact ... as their parent drug ... Analogues will not necessarily behave in the same way or have a similar harm profile to their parent drug.

The new mechanism under the PSA instead considers each individual psychoactive product to determine the level of risk a product may pose in accordance with the effects it has on individual health. This will ensure individuals are not prevented from consuming psychoactive products, which pose no more than a low risk of harm, merely because they share structural similarities with products which do pose a higher risk of harm.

The aforementioned requirements under the MoDA were problematic. As established under Part VI, it is in the public's interest for the state to act paternalistically and control the supply and use of harmful psychoactive substances. Without the existence of further regulation, it was difficult for the state to protect vulnerable individuals from the harmful effects of certain psychoactive substances. The reality was that the MoDA was entirely insufficient to deal with the global problem of psychoactive substances and a new regulatory system was required.

\section{Is the Psychoactive Substances Act Sufficient to Control and Monitor Psychoactive Substances in New Zealand?}

\begin{tabular}{ll}
\hline 01 & Misuse of Drugs Act, s 4D(5). \\
102 & (9 April 2013) 689 NZPD 9133. \\
103 & Law Commission, above n 92, at 115. \\
104 & At 115-116.
\end{tabular}


The purpose of the PSA is to "regulate the availability of psychoactive substances in New Zealand to protect the health of, and minimise harm to, individuals who use psychoactive substances". ${ }^{105}$ The PSA has reversed the onus that was previously on the Minister to prove a psychoactive substance posed a risk of harm. ${ }^{106}$ Instead, the onus is now on the manufacturers and importers of psychoactive products to prove to the Psychoactive Substances Regulatory Authority (the Authority) ${ }^{107}$ that each product they submit for approval only poses a low risk of harm to consumers. ${ }^{108}$

The PSA is inherently paternalistic and restricts individual autonomy to protect people from making poor decisions based off a lack of understanding about the harms that some psychoactive products may cause. In this way, the PSA is restricting the autonomy of the very people it aims to protect. At the same time, the PSA inhibits the freedom of manufacturers, importers and retailers of psychoactive products. It is difficult to ascertain how the psychoactive substances industry will benefit from this new regulatory regime. Consequently, it is important to determine whether such restrictions are justifiable in accordance with Part VI of this paper.

\section{A What is the Scope of the Psychoactive Substances Act?}

This Act applies to the importation, manufacture, sale, supply, or possession of a psychoactive substance for the primary purpose of inducing a psychoactive effect in an individual who uses the substance. ${ }^{109}$

For a substance to come under the ambit of the PSA it must have a "primary purpose of inducing a psychoactive effect". 110 This provision is in line with the NZDF's recognition that "as most inhalants in New Zealand are common household products, it is not practical to make them illegal". 111 The NZDF also identified "although it is not illegal to possess inhalants, police can hold people under the influence of inhalants for detoxification under the Alcoholism and Drug Addiction Act 1966". ${ }^{112}$ Whilst the use of

\footnotetext{
$105 \quad$ Psychoactive Substances Act, s 3.

106 Misuse of Drugs Act, s 4C(3).

107 Psychoactive Substances Act, s 10.

$108 \quad$ Section 37.

109 Section 5(1).

110 Section 5(1).

111 New Zealand Drug Foundation "Inhalants and Solvents" (28 August 2013)<http://www.drug foundation.org.nz>.

$112 \quad$ New Zealand Drug Foundation, above n 111.
} 
such products by individuals for the purpose of obtaining a psychoactive effect is of concern, it would be impractical to require household items, such as petroleum, to pose no more than a low risk of harm before they can be provided to the public. In accordance with Dworkin's analysis of state paternalism, it would be overly paternalistic of the state to prevent the proper use of such items by individuals who are not causing a risk of harm to themselves or to others in society.

Nevertheless, the broad definition of "psychoactive substance" will still enable authorities to bring substances that are masqueraded as other products under the scope of the PSA. Iain Lees-Galloway MP has affirmed: ${ }^{113}$

... anybody out there who thinks they can be a bit cute and try to call something by another name, and everybody knows it can be used as a psychoactive substance and can be ingested by a human being as a drug for a psychoactive effect - this clause will capture it. It does not matter what they call it.

The provision Mr Lees-Galloway was referring to is now s 99 of the PSA. Section 99 allows the Governor-General to declare a substance to be a psychoactive substance for the purposes of the Act. Substances that are used only for one purpose, to induce a psychoactive effect, and are masqueraded as another product may still be brought under the ambit of the PSA. ${ }^{114}$ Consequently, in situations where these items are consumed in a dangerous manner, a loophole exists whereby the state can still act paternalistically, in such a way where individual autonomy is infringed upon the least.

\section{B Are There Any Cultural Concerns that Arise as a Result of the Psychoactive Substances Act?}

Historically, psychoactive substances have been used by (i) priests in religious ceremonies (e.g. amanita muscaria); (ii) healers for medicinal purposes (e.g. opium); or (iii) the general population in a socially approved way (e.g. alcohol, nicotine and caffeine). ${ }^{115}$

Psychoactive substances have been used by indigenous populations for centuries; and are, without a doubt, important to many cultures in New Zealand. However, it is uncertain as

\footnotetext{
(9 July 2013) 692 NZPD 11777.

114 Psychoactive Substances Act, s 99(1).

115 Marc-Antoine Crocq “Historical and Cultural Aspects of Man's Relationship with Addictive Drugs" (2007) 9(4) Dialogues in Clinical Neuroscience 355 at 355.
} 
to whether substances, which pose more than a low risk of harm to individuals or society, should be permitted only because they are part of a cultural identity.

\section{$1 \quad K a v a$}

Kava is a prominent and pervasive force in daily life of the people in Fiji, Vanuatu, Tonga, the Samoas, and... other small island countries. This force or power has been interpreted in a number of ways, including as a link to the gods, maintaining a hierarchy in Pacific societies, as a mind altering drug, or as a symbol of national identity. ${ }^{116}$

During the first reading of the PSA, Kris Faafoi MP identified how important kava was to certain communities within New Zealand: ${ }^{117}$

... there is a lot of cultural significance attached to the 'ava and kava ceremonies. For the Tongan community, for the Samoan community, and for the Fijian community it will be a psychoactive substance...

The claimed health benefits of kava are also extensive: ${ }^{118}$

...historically, kava was considered to have beneficial effects on health. The Hawaiians used it for many purposes, including to soothe the nerves, induce relaxation and sleep, counteract fatigue, relieve congestion in the urinary tract, alleviate symptoms of asthma and rheumatism, and reduce weight.

Nevertheless, such claims are controversial. Recent studies have demonstrated that the consumption of kava produced by non-traditional means may also harm individual health. In 2008, the University of Sydney performed a study that found "following kavain treatmen ... liver tissue displayed an overall change in structure". ${ }^{119}$ Consequently, such "concerns about the dangers of kava and the effects on the liver have resulted in regulatory agencies ... banning or restricting the sale of kava". ${ }^{20}$

\footnotetext{
$116 \quad$ Yadhu N Singh "Kava: An old drug in a new world” (2009) 71 Cultural Critique 107 at 109.

$117 \quad$ (9 April 2013) 689 NZPD 9145.

118 Yadhu N Singh, above n 116, at 119.

119 Science News “Kava Linked to Liver Damage, New Evidence Shows" Science News (online ed, Maryland, 28 February 2008) <http://www.sciencedaily.com>. 
As identified by Mr Faafoi, kava is not expressly excluded from the ambit of the Act. ${ }^{121}$ Section 9, which defines the meaning of "psychoactive substance", does not limit the scope of the PSA to substances which are only synthetic, otherwise known as chemical, in nature. Mr Dunne responded to this concern and asserted that "kava is already suitably regulated through other legislation and [the PSA] will have absolutely no effect on that". ${ }^{122}$ The Australia New Zealand Food Standards Code, referred to under the Food Act $1981,{ }^{123}$ regulates the traditional use of kava when it is consumed as a drink. ${ }^{124}$ Consequently, the PSA excludes substances that are already regulated as "food" under the Food Act. ${ }^{125}$

Mr Dunne declared that kava will also be covered by the Natural Health and Supplementary Products Bill 2013 (NHSPB). ${ }^{126}$ However, this assurance is entirely dependent on two uncertainties. Firstly, the NHSPB will have to be enacted for this to apply. Secondly, if the NHSPB is enacted, the PSA will have to be amended to stipulate that substances, which already come under the scope of the NHSPB, are excluded from the ambit of the PSA. Nevertheless, cl 9 of the NHSPB refers to a product that "is, or appears to be, manufactured for human use; and for the primary purpose of bringing about a health benefit to the person who uses the product". ${ }^{127}$ If kava is consumed by an individual for the purpose of bringing about a health benefit, it may come under the scope of the NHSPB.

The PSA provides a good balance, whereby traditional uses are permitted and other uses, which may cause individual harm, are restricted. The autonomy of different cultural groups within New Zealand will not be unduly infringed upon, and yet, harmful forms of kava, produced in a non-traditional manner, may still be prohibited in order to protect individuals who lack a sufficient understanding of the risks. Accordingly, this differentiation may help traditional users to distinguish between harmful and non-harmful forms of kava.

\footnotetext{
(9 April 2013) 689 NZPD 9145.

122 Peter Dunne “Dunne: Kava unaffected by Psychoactive Substances Bill” (press release, 11 April 2013).

123 Food Act 1981, s 2.

$124 \quad$ Australia New Zealand Food Standards Code 2000, Standard 2.6.3.

125 Food Act 1981, s 9(3)(f).

126 Peter Dunne, above 122.

$127 \quad$ Natural Health and Supplementary Products Bill 2013 (324-2), cl 6.
} 


\section{Betel}

"Betel is a compound of several natural substances chewed for its mild psychostimulating effects." 128 It is believed that "approximately 200 million people chew betel regularly throughout the western Pacific basin and South Asia". ${ }^{29}$ When betel is chewed it produces a psychoactive effect for the individual user and is often of cultural importance: ${ }^{130}$

Betel and betel chewing are integral components of the cultural fabric for 20 [per cent] of the human population. The quantity, frequency, and age that one starts chewing betel vary by local traditions... in addition to its role in daily life, betel is a symbolic offering on occasions of welcoming guests and paying homage, courtship and betrothal, funerals and ancestral remembrances, reconciliation and peace-making, and in the practice of traditional medicine.

The substances used to create betel are currently available in New Zealand. ${ }^{131}$ If it is brought under the ambit of the PSA, it is uncertain whether it will obtain approval as research has demonstrated that the regular use of betel may cause oral cancer to develop. ${ }^{132}$

3 Should psychoactive substances that are linked to a cultural identity be excluded from the ambit of the Psychoactive Substances Act?

This paper recognises that, on one hand, it appears logical in the interests of cultural understanding for substances that are created and used in a traditional manner to be excluded from the ambit of the Act. Section 99 would allow the Governor-General to declare traditional substances, such as kava or betel, not to be psychoactive substances for the purpose of the Act. Previous prohibitions on traditional psychoactive substances have also been linked to a lack of cultural collectiveness in certain communities and an

\footnotetext{
Scott A Norton "Betel: Consumption and Consequences" (1998) 38(1) Journal of American Academy of Dermatology 81 at 81 .

131

At 81 .

At 83.

P Yoganathan "Betel Chewing Creeps into the New World" (2002) 98 The New Zealand Dental Journal 40 at 40.

Colin Binns, Wan Yun Low and Katie Hewitt "Betel Chewing and Public Health" (2011) 23(6) Asia-Pacific Journal of Public Health 1021 at 1021.
} 
increase in violence. ${ }^{133}$ However, it would be illogical and undesirable, having determined that psychoactive substances pose a risk of harm that justifies state intervention, to allow certain substances to cause harm on the basis that they form part of a cultural identity. The risks to individual health may also justify the prohibition of such substances in order to protect society from related fiscal costs. Nevertheless, it seems unreasonable to place the burden of proving that a traditional psychoactive substance poses no more than a low risk of harm on the cultural community of which PSA adversely affects. Instead, this paper proposes that the burden to pay for the testing of such substances should be placed on the state.

\section{Is the Requirement that all Individuals and Body Corporates must have Licences to Import, Manufacture, Research or Sell Psychoactive Substances Warranted?}

\section{Interim Licences}

The PSA allows for a "transitional arrangement", whereby a "psychoactive substance or product may continue to be imported, manufactured, researched, or sold after the commencement of [the Act]", 134 provided that it has "lawfully being imported, manufactured, researched, or sold throughout the period of 3 months immediately before the commencement of [the] Act. ${ }^{135}$ If importers, manufacturers, researchers and retailers want to continue importing, manufacturing, researching or selling such products during this transitional period, they must apply for, and obtain, an interim licence. ${ }^{136}$

Each applicant for a licence must provide "written consent... for the Authority to access any personal information about the applicant relevant to the application, including (without limitation) any police records". ${ }^{137}$ The Authority may then use the information provided to determine whether an applicant is a fit and proper person to hold such a licence. Since the enactment of the PSA, two licences have been refused, two licences have been suspended, and one licence has been cancelled by the Authority. ${ }^{138}$

\footnotetext{
133 Sione Pinomi "Kava restriction puts an unfair burden on Pacific culture" The Sydney Morning Herald (online ed, Sydney, 30 May 2013) <http://www.smh.com.au>. Psychoactive Substances Act, sch 1(2).

Schedule 1(2).

Schedule 1(2).

Schedule 1(7)(3).

Ministry of Health "Interim Licences" (03 October 2013)<http://www.health.govt.nz>.
} 
Psychoactive substances are able to cause significant harm to individual consumers and society. Therefore, it is important to ensure that individuals, who have previously demonstrated a lack of regard for the wellbeing of individuals and society, are excluded from dealing in psychoactive products. Since the enactment of the PSA, approximately 110 retail licences have been issued. ${ }^{139}$ However, once the Psychoactive Substances Regulations come into effect, interim licences will be revoked unless, within 28 days after the establishment of the regulations, the individual or body corporate completes a full application for a licence under s 13 of the PSA. ${ }^{140}$

\section{Applications for licences}

Licences under the PSA must be obtained before an individual or body corporate can import psychoactive substances, ${ }^{141}$ manufacture psychoactive substances, ${ }^{142}$ research psychoactive substances, ${ }^{143}$ sell psychoactive substances that are not approved products, ${ }^{144}$ sell approved products by retail, ${ }^{145}$ and sell psychoactive substances by wholesale. ${ }^{146}$ In order to obtain any of these licences, the application made must include "any particulars, information, documents or other material required by the Authority and prescribed in the regulations" 147 and "the prescribed fee". ${ }^{148}$

This mandatory requirement is an instance of impure paternalism, whereby the state prohibits unlicensed individuals and body corporates from manufacturing, importing and selling psychoactive substances to protect the health of individual consumers. Such state intervention is justified because of the extensive amount of harm that unregulated psychoactive substances may impose on individual consumers and society. Prior to the enactment of the PSA, the psychoactive substances industry took advantage of the lack of regulation to sell high risk psychoactive products for financial gain. ${ }^{149}$ To allow such

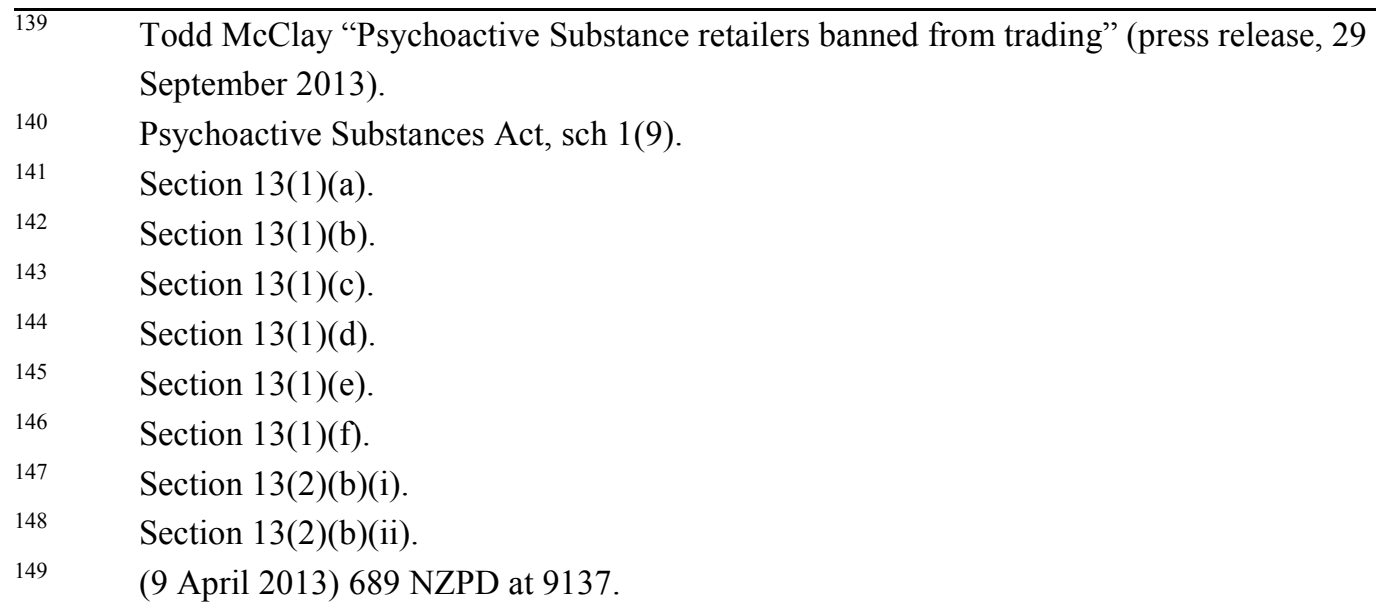


individuals and corporations to remain unlicensed and unregulated would impose an unacceptable risk of harm on individuals and society.

Section 16(1)(c) requires that "for an application made by an individual, the applicant is a fit and proper person to hold the licence". Section 16(2) outlines what the Authority shall consider when determining whether a person is "fit and proper" to hold a licence:

(a) whether the applicant has been convicted of a relevant offence; and

(b) whether there has in the past been a serious or repeated failure by the applicant to comply with any requirement of this Act; and

(c) whether there are other grounds for considering that the applicant is likely in the future to fail to comply with any requirement of this Act; and

(d) any other matter that the Authority considers relevant.

The term "relevant offence" is defined in section 16(3) as including: ${ }^{.150}$

(a) an offence against this Act; or

(b) an offence against the Misuse of Drugs Act 1975 or the Misuse of Drugs Amendment Act 2005 or any regulations made under those Acts; or

(c) an offence against the Medicines Act 1981; or

(d) a crime involving dishonesty (as defined in section 2(1) of the Crimes Act 1961).

It would be illogical to allow applicants, who have previously disregarded laws designed to protect the safety of individual consumers, the opportunity to cause further harm to such individuals. Section 16(1)(d) also requires "for an application made on behalf of a body corporate, [that] the body corporate is of good repute". ${ }^{151}$ No definition or method of determining whether a body corporate is of good repute is provided under the Act. Consequently, the Authority will have to interpret the term without further guidance each time they consider an application from a body corporate.

Licences granted by the Authority will generally last for 3 years from the date of issue. ${ }^{152}$ Section 22(1)(d) allows for the suspension or cancellation of licences where a licence holder has ceased to be a fit and proper person to hold a licence, or a body corporate of good repute. This provision will ensure that licences continue to be held only by

\begin{tabular}{ll}
\hline 150 & Section $16(3)$. \\
151 & Section $16(1)(d)$. \\
152 & Psychoactive Substances Act, s 19.
\end{tabular}


individuals and body corporates who are willing to comply with the requirements under the PSA.

\section{Offences relating to licences}

Section 24 establishes that it is an offence to provide materially false or misleading information during the application process. ${ }^{153}$ Any person who commits this offence "is liable on conviction to a term of imprisonment not exceeding 3 months or a fine not exceeding \$500,000, or both". ${ }^{154}$ The substantial penalties imposed for this offence are justified. The licencing regime under the PSA has a purpose of excluding undesirable individuals from obtaining such licences. The penalties imposed under s 24 will dissuade individuals who are not "fit and proper" to hold such licences, from providing false information in an attempt to obtain a licence.

Sections 25-26 also provide penalties for importing or manufacturing psychoactive substances without a licence. ${ }^{155}$ The penalties for importing or manufacturing psychoactive substances without a licence are: ${ }^{156}$

(a) in the case of an individual... a term of imprisonment not exceeding 2 years

(b) in the case of a body corporate... a fine not exceeding $\$ 500,000$

Section 27 also establishes that any individual who sells an approved product without possessing a licence is liable to a "term of imprisonment not exceeding 3 months, or a fine not exceeding $\$ 40,000 "$ ".

These penalties are valuable as they will dissuade individuals who are unwilling to comply with the requirements under the Act from manufacturing or importing psychoactive substances. By ensuring all importers, manufacturers, and retailers of psychoactive products are licenced, enforcement officers will know which individuals and body corporates are dealing in psychoactive substances and products. As a result, they will be able to monitor such individuals and body corporates to ensure continuous compliance with the PSA.

\begin{tabular}{ll}
\hline 153 & Section 24(1). \\
154 & Section 24(2). \\
155 & Sections 25-28. \\
156 & Sections 25-28.
\end{tabular}




\section{How can a Psychoactive Product Become an Approved Product?}

Section 4(a) states "a psychoactive product that is approved for use by individuals should pose no more than a low risk of harm to individuals who use it". ${ }^{157}$ The PSA ensures that each individual psychoactive product must be proven to pose no more than a low risk of harm before it can be sold to the public. Even if a psychoactive product includes the same ingredients as a previously approved product, it will still be required to gain approval through the Authority. Each individual product will be evaluated under the PSA, which means that harmful products will not be able to be masqueraded as something they are not.

\section{Interim approvals of psychoactive products}

The PSA establishes that "a person who is a New Zealand resident may, within 28 days after the commencement of this Act, apply for the interim approval of a psychoactive product". ${ }^{158}$ The transitional arrangement under the PSA allows psychoactive products, which were lawfully sold within the three month period prior to the enactment of the PSA, to continue to be imported, manufactured, researched or sold. ${ }^{159}$ Although applicants are not required to provide information from preclinical and clinical trials, the applications for the interim approval of products are heavily scrutinised by the Authority and the Interim Psychoactive Substances Expert Advisory Committee (IPSEAC). ${ }^{160}$

The Authority has established a temporary risk assessment method to determine whether a psychoactive product poses more than a low risk of harm. "Products with a combined risk score of greater than [two] pose more than a low risk of harm to a consumer." 161 The risk level of a product is determined by reference to the reported number of adverse effects. Each minor adverse effect is given a score of one, a moderate adverse effect is given a score of two, a severe adverse effect is given a score of three, and each adverse effect relating to withdrawal is given a score ranging from one to three. ${ }^{162}$ Consequently, an application for interim approval of a product will be rejected if, for example, three individuals have previously suffered minor adverse effects after consuming the

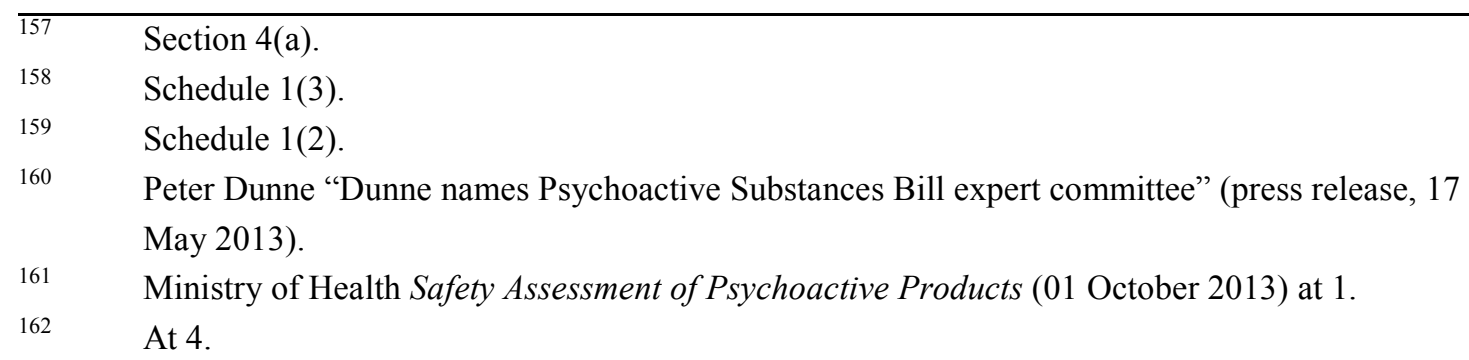


psychoactive product. Since the enactment of the PSA, the Authority has "refused applications for six products seeking interim approval". ${ }^{163}$ These products were denied approval due to the various "reports of adverse reactions from a range of sources including the National Poisons Centre and hospital emergency departments". 164 The Authority has acknowledged that it is acting on the side of caution, whereby, products must pose only a very low risk of harm to obtain interim approval. ${ }^{165}$

\section{Applications for Approval of a Product}

The Authority has declared that once the Psychoactive Substances Regulations are in place, individuals applying for the approval of a product: ${ }^{166}$

... will be required to submit a research plan designed to conclusively demonstrate the product poses no more than a low risk of harm to a consumer along with data on the safety and quality of their product.

The degree of harm a psychoactive product poses to individual consumers will be determined by the Authority. ${ }^{167}$ To assist the Authority with this task, the Psychoactive Substances Expert Advisory Committee (PSEAC) will analyse the available information on each product and advise the Authority accordingly. ${ }^{168}$ As acknowledged by the current Associate Minister of Health, the Hon Todd McClay MP, the PSA "was never meant to be a ban by stealth". ${ }^{169}$ Accordingly, the PSA states that "a psychoactive product that poses no more than a low risk of harm to individuals who use the product should be approved". ${ }^{170}$ At the same time, the focus on individual health and safety is affirmed by s 4(d) which states "a psychoactive product that poses more than a low risk of harm to individuals who use the product should be prohibited". ${ }^{171}$ Section 4(e) also prohibits all psychoactive products on a precautionary basis until they have been approved by the Authority.

\footnotetext{
$163 \quad$ Fuseworks Media “Authority refuses approval for psychoactive products” Voxy (online ed, New Zealand, 27 September 2013) <http://www.voxy.co.nz>.

164 Fuseworks Media, above n 163.

165 Ministry of Health Safety Assessment of Psychoactive Products, above n 161, at 1

166 At 2.

167 Psychoactive Substances Act, s 4(b).

168 Section 4(b).

$169 \quad$ (27 June 2013) 691 NZPD 11390.

170 Psychoactive Substances Act, s 4(c).

$171 \quad$ Section $4(d)$.
} 
Section 37 establishes the grounds for approving a product: ${ }^{172}$

The Authority must approve a psychoactive product as an approved product if the Authority is satisfied that -

(a) the application relating to the product -

(i) complies with the requirements of section 33; and

(ii) does not contain any materially false or misleading information; and

(b) the degree of harm that the product poses to individuals using the product is no more than a low risk of harm

For an application to be approved, the applicant must have complied with s 33. Section 33(2) stipulates that an individual applying for approval of a product must provide any information that the Authority requests. This provision is a key component of the PSA, as such information will enable the Authority to make an informed and accurate assessment of the risk of harm a product may pose to consumers.

Section 33(2) also requires the applicant to pay "the prescribed fee (if any)". ${ }^{173}$ The Psychoactive Substances Regulations, expected to be in place by late 2013, will stipulate the "processes and fees required for new product approvals". ${ }^{174}$ However, Mr Dunne acknowledged that each application for approval of a product will cost up to $\$ 180,000 .{ }^{175}$ It has also been estimated that the testing of an individual product will cost around $\$ 2,000,000$. $^{176}$ These costs are reasonable when one considers that the individuals who will be applying for approval are representatives of corporate bodies. These corporations have made substantial profits over the years through the sale of psychoactive substances and will continue to do so after approval is granted. ${ }^{177}$

\section{Offence relating to application for approval}

Section 41(1) states:

\begin{tabular}{ll}
\hline 172 & Section 37. \\
173 & Section 33(2)(b)(ii). \\
174 & Ministry of Health "Psychoactive Substances Regulatory Authority: Distribution of Psychoactive \\
& Substances and Products in New Zealand" (26 July 2013) <http://www.health.govt.nz>. \\
175 & Peter Dunne "Dunne bans substance found in K2 testing" (press release, 26 November 2012). \\
$176 \quad$ & Jared Savage "Drug designers stay one step ahead" The New Zealand Herald (Online ed, New \\
& Zealand, 10 June 2013) <http://www.nzherald.co.nz>. \\
& (9 April 2013) 689 NZPD at 9137.
\end{tabular}


A person commits an offence in respect of an application for the approval of a psychoactive product if the person -

(a) provides information that the person knows, or ought to know, is materially false or misleading; or

(b) fails, without reasonable excuse, to provide any relevant information relating to -

(i) the ingredients of the product; or

(ii) the effect of the product on individuals who use the product.

Section 41(2) establishes that a person who commits an offence under s 41(1) "is liable on conviction to a term of imprisonment not exceeding 3 months or a fine not exceeding $\$ 500,000$, or both". The penalties for this offence are substantial, however, the information gathered on each psychoactive product submitted for approval enables the Authority to ensure only low risk products are made available to the public. It would be illogical to allow applicants to provide false information or to mislead the authority about the risk level of a product. If an applicant fails to inform the authority about a potential adverse effect that a product may cause, and that product is subsequently approved, it may have serious implications for an individual consumer who later suffers that adverse reaction. As a result, it is important to restrain the actions of the psychoactive substances industry, and impose substantial penalties for non-compliance with the Act, to protect consumers and society from such instances of harm.

\section{E How Will the Authority Determine Whether a Psychoactive Product Poses Only a Low Risk of Harm?}

The PSEAC will "evaluate, with regard to the results of trials, psychoactive products to assess whether they should be approved for use by individuals", 178 and "advise the Authority about whether a psychoactive product should or should not be approved for use by individuals". ${ }^{179}$ Section 11(4) states that: ${ }^{180}$

... the advisory committee may comprise up to 6 members who between them must have appropriate expertise in -

(a) pharmacology:

(b) toxicology:

\begin{tabular}{ll}
\hline 178 & Psychoactive Substances Act, s 11(2)(a). \\
179 & Section 11(2)(b). \\
180 & Section 11(4).
\end{tabular}


(c) neurosciences:

(d) medicine:

(e) any other areas the Authority considers relevant

This provision establishes that members of the PSEAC will be required to combine knowledge in different areas of expertise to ensure only psychoactive products that pose a low risk of harm are approved. This provision provides a much greater level of guidance to the Authority than the current method of establishing Ministerial committees provides to the Minister of Health under the New Zealand Public Health and Disability Act 2000 (NZPHDA). Section 11(1)(b) of the NZPHDA establishes that the Minister may "appoint any person to be a member or chairperson of the committee". ${ }^{181}$ No further guidance is provided in the NZPHDA as to which fields of expertise members should be familiar with. Furthermore, with the exception of the four members chosen by the Minister, the majority of each District Health Board (DHB) in New Zealand is comprised of members who have been voted in by the New Zealand public. ${ }^{182}$ Consequently, is uncertain whether the use of this method produces a DHB that possesses the necessary level of medical and legal knowledge.

Section 11(4)(e) establishes that the Authority may choose members from other fields of expertise. ${ }^{183}$ This will, in theory, allow a legal professional to be appointed as a member of the PSEAC. Section 11(10) determines that the PSEAC must "act independently; and ... comply with natural justice". ${ }^{184}$ The inclusion of a legal professional may help to ensure that the processes comply with these legal requirements, and subsequently, may lead to fewer appeals. ${ }^{185}$

The Centre for Addiction Research has also advocated that a specialist in the field of addiction should be a member of the PSEAC. ${ }^{186}$ An expert in addiction may be able to determine whether the use of a psychoactive product is likely to cause individual consumers to become dependent on that psychoactive product. This will help to minimise the harms caused by such dependence, including the injuries to individual health and fiscal costs to society.

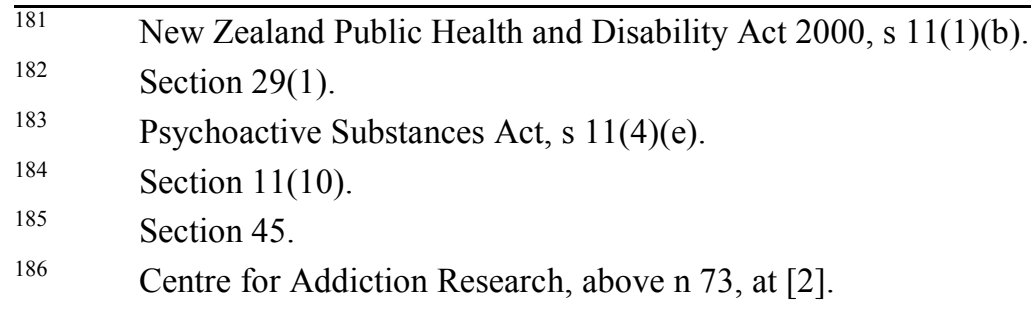


To assist the PSEAC with establishing whether a product will pose only a low risk of harm, the Health Select Committee established a list of matters to which the PSEAC must have regard: ${ }^{187}$

(a) the specific effects of the product, including pharmacological, psychoactive, and toxicological effects; and

(b) the risks, if any, to public health; and

(c) the potential for use of the product to cause death; and

(d) the ability of the product to create physical or psychological dependence; and

(e) the likelihood of misuse of the product; and

(f) the potential appeal of the product to vulnerable populations; and

(g) any other matters that the Authority considers relevant.

1 "The specific effects of the product including pharmacological, psychoactive, and toxicological effects"

This provision is essentially vague and does not explicitly preclude the PSEAC from considering both the positive and negative effects of a product. Consequently, this provision may allow the PSEAC to perform a balancing act, whereby the positive aspects of a product may be weighed against the negative aspects of a product.

Furthermore, little information is provided as to whether the long-term effects of a product will be considered by the PSEAC. It is foreseeable that certain adverse effects, which arise from the use of psychoactive substances, will only occur after prolonged use of a product. For example, the regular use of betel over a prolonged period of time may cause oral cancer to develop years after the date of initial consumption. ${ }^{188}$

\section{2 "The risks, if any, to public health"}

This requirement makes it apparent that, despite not being mentioned as a purpose or principle under the PSA, the Act, in reality, regulates psychoactive substances in order to provide protection not only to individual consumers, but also to society in general. However, it is uncertain as to whether this requirement would protect society from many of the harms, identified in Part $\mathrm{V}$ of this paper, which may result from the use of psychoactive substances. For example, it is unlikely that the potential for the use of a product to impose significant financial costs upon society will be considered under this

\footnotetext{
$187 \quad$ Psychoactive Substances Act, s 11(3).

188 Colin Binns, Wan Yun Low and Katie Hewitt, above n 132, at 1021.
} 
provision. Instead, it is likely that the Authority will have to utilise its own discretion and incorporate such concerns under "any other matters that the Authority considers relevant". ${ }^{189}$

\section{3 "The potential for use of the product to cause death"}

The study generated on the past use of GHB, considered in Part V of this paper, demonstrated that the use of certain psychoactive substances may result in death. If the use of a psychoactive product is able to cause the death of an individual consumer, it certainly poses more than a low risk of harm and should certainly not obtain approval under the PSA.

\section{4 "The ability of a product to create physical or psychological dependence"}

Section 11(3)(d) addresses the concern that some psychoactive substances may pose a long term risk of substance dependence. As previously established in Part VI, the existence of substance dependence may negatively affect an individual's ability to exercise their right to autonomy. It would be illogical to allow addictive psychoactive products to be consumed by individuals, who may, like the young man in Oamaru, resort to criminal activities in an attempt to fund their habit. ${ }^{190}$

\section{5 "The likelihood of misuse of the product"}

The PSEAC's consideration of this factor may be useful in situations where information is available which demonstrates that a psychoactive product has, prior to the PSA, been consumed regularly by individuals in quantities that are higher than the recommended dosage. However, when an application is for a product that contains only new psychoactive substances, which have never before been available to the public, the likelihood of misuse may be difficult to determine.

\section{6 "The potential appeal of the product to vulnerable populations"}

As identified by Mill, some individuals, including minors, lack the ability to make good autonomous decisions. ${ }^{191}$ The PSA imposes various restrictions on the psychoactive

\begin{tabular}{ll}
\hline 189 & Psychoactive Substances Act, s 11(3)(b). \\
190 & Rebecca Ryan, above n 64. \\
191 & John Stuart Mill, above n 60, at 22-23.
\end{tabular}


substances industry in an attempt to ensure that minors are not exposed to, or attracted by, psychoactive products. This consideration will allow the PSEAC to determine whether features, such as the name or contents of a product, have the potential to appeal to minors or other vulnerable populations.

\section{F What Level of Evidence will be required by the Authority to determine whether a Psychoactive Product poses only a Low Risk of Harm?}

Section 8 defines trial as "a preclinical or clinical trial, and includes research, testing and teaching". ${ }^{192}$ Section 4(b) stipulates that the Authority should have regard to evidence, which includes the results of preclinical and clinical trials, before a product is approved. ${ }^{193}$ Preclinical trials involve a laboratory test as part of the process of proving that there is a sufficient level of evidence to justify a clinical trial. ${ }^{194}$ They exist to determine "the starter range of doses to be tested in people, as well as the format to be used-syrup, capsule, pill or injection". ${ }^{195}$ Medsafe has defined the term clinical trial as "the scientific study of a new device design, application, or treatment that is conducted to collect data on the safety and efficacy of the invention". ${ }^{196}$ Whilst this is a good definition, the efficacy of psychoactive products will not be considered by the PSEAC. ${ }^{197}$ The PSA does not specify how extensive trials will have to be; however, it is apparent that the information gathered must be of an adequate level for the PSEAC and the Authority to determine whether a product poses only a low risk of harm.

The Centre for Addiction Research submitted that the required trials should be performed by a set body of independent researchers. ${ }^{198}$ The pharmaceutical industry has often been criticised for the manufacturer's ability to publish and provide only information which supports their case. ${ }^{199}$ If manufacturers and importers are able to omit evidence, which establishes that certain products pose more than a low risk of harm, individual consumers

\footnotetext{
$192 \quad$ Psychoactive Substances Act, s 8.

193 Section 4(b).

194 Medicines and Healthcare Products Regulatory Agency "My Medicine: Preclinical Research" (25 September 2008) <http://www.mhra.gov.uk> at 1.

195 Medicines and Healthcare Products Regulatory Agency, above n 192, at 1.

196 Medsafe "Conducting Medical Device Clinical Trials in New Zealand” (10 May 2011)

$<$ http:// www.medsafe.govt.nz>.

$197 \quad$ Psychoactive Substances Act, s 11.

198 Centre for Addiction Research, above n 73, at [1].

199 Gunraj Sandhu "Drug firms withholding data on bad trials: Dr Wollaston" Top News Arab Emirates (online ed, Abu Dhabi, 24 October 2012) <http://www.topnews.ae>.
} 
would often be unable to make an informed decision on whether to use such psychoactive products.

Despite the list of effects and potential harms that the PSEAC must have regard to, there are still matters that require further consideration. A fundamental question, which remains to be answered, is whether the method of use will be tested for harmful effects. It has been established that smoke inhalation can have a detrimental effect on individual health and may cause throat cancer. ${ }^{200}$ In order for products to be entirely evaluated for the risks they pose to individual and public health, the method of consumption should also be evaluated during preclinical and clinical trials.

An additional benefit to society is that the PSEAC will release reports on the substances that they have subjected to risk evaluations. ${ }^{201}$ The PSA also establishes an Internet-based register that will list the products that have gained approval. ${ }^{202}$ An important component of the PSA is the choice it provides to individual consumers. Consumers are able to choose to use psychoactive products that may pose a low risk of harm. In Part VI of this paper, Tom Beauchamp and James Childress considered that a proper understanding of the decision at hand is required before an individual can act autonomously. ${ }^{203}$ The reports released by the PSEAC will provide consumers with unbiased information about psychoactive products. As a result, individuals will have the opportunity to gain an understanding of the risks of each product and subsequently, will be able to make an informed decision on whether or not to consume a particular psychoactive product.

\section{G Where Can Psychoactive Products Be Sold or Supplied?}

The Law Commission recommended that: ${ }^{204}$

... the sale or supply of approved substances should be prohibited from:

(a) places where alcohol is sold;

(b) petrol stations;

(c) non-fixed premises such as vehicles, tents and mobile street cars; and

\footnotetext{
200 American Dental Education Association "Tobacco use and oral cancer: a global perspective" 65 Journal of Dental Education 328 at 328.

201 Psychoactive Substances Act, s 11(2)(c).

202 Section 43(3).

203 Tom Beauchamp and James Childress, above n 63, at 99.

204 Law Commission, above n 92, at 25.
} 
(d) places where children gather (Such as schools, recreational facilities and sports facilities).

Section 52 provides a list of places and premises at which psychoactive products are prohibited from being sold. Included in this list are dairies, ${ }^{205}$ convenience stores, ${ }^{206}$ grocery stores and supermarkets, ${ }^{207}$ service stations, ${ }^{208}$ outlets that sell or provide alcohol, ${ }^{209}$ premises that are not a fixed permanent structure, ${ }^{210}$ any vehicle or other conveyance, $^{211}$ and any other places or premises listed under potential future regulations. $^{212}$

\section{Minimising the level of exposure to psychoactive products by minors}

These prohibitions on the sale and supply of psychoactive products were formed by the Health Select Committee in an attempt to minimise the level of exposure of such products to young persons. It is logical to assume that by removing these products from places where individuals under the age of 18 years old frequent, the level of exposure will decrease.

Section 48(1) also stipulates that it is an offence for any individual to sell psychoactive products to other individuals under the age of 18 years old. Section 48(2) determines that:

A person who contravenes subsection (1) commits an offence and is liable on conviction -

(a) In the case of an individual, to a fine not exceeding $\$ 5,000$ :

(b) In the case of a body corporate, to a fine not exceeding $\$ 10,000$.

These restrictions on where products may be sold, and to whom they may be sold to, are reasonable. The state already restricts the autonomy of minors for their own protection; for example, only individuals 18 years old and over can purchase alcohol in New Zealand. ${ }^{213}$ As acknowledged by Mill, young persons may often lack the level of maturity

\begin{tabular}{ll}
\hline 205 & Psychoactive Substances Act, s 52(1)(a). \\
206 & Section 52(1)(b). \\
207 & Section 52(1)(c). \\
208 & Section 52(1)(d). \\
209 & Section 52(1)(e). \\
210 & Section 52(1)(f). \\
211 & Section 52(1)(g). \\
212 & Section 52(1)(h). \\
213 & Sale of Liquor Act 1989, s 155.
\end{tabular}


or understanding required to make good autonomous decisions. ${ }^{214}$ If individuals cannot fully understand the risk of harm that psychoactive products may pose, their decision to use such products is uninformed. Consequently, the state is justified in limiting the autonomy of retailers to protect such vulnerable individuals from harm.

\section{The combined consumption of alcohol and psychoactive products}

The National Community Action Youth and Drugs Advisory Group submitted that "evidence from research on illicit drugs suggests the combined consumption of psychoactive substances and alcohol increases the misuse and immediate risk of harm from such drugs". ${ }^{215}$ Such harm can also have an adverse effect on society as a whole, through both increased levels of violence, ${ }^{216}$ and the fiscal costs of hospitalisation for individuals who suffer adverse reactions. ${ }^{217}$ Section $52(1)(\mathrm{e})$ of the PSA, which prohibits the sale of psychoactive products at premises where alcohol is sold or supplied, will help to minimise this harm. Firstly, this provision will remove any implication that such substances may safely be consumed together because they can both be purchased from the same location. Secondly, it will make it more difficult for individuals to obtain both substances at the same time.

\section{The quantity of psychoactive products that may be sold to an individual}

This paper proposes that it would be logical to limit the quantity of products a retailer may provide to an individual. Such a restriction would serve as a reminder to individual consumers that only the amount stipulated on the package of a product should be consumed.

\section{H How Can Psychoactive Products Be Advertised?}

The Law Commission recommended that the advertising of psychoactive products: ${ }^{218}$

\footnotetext{
$214 \quad$ John Stuart Mill, above n 60, at 22-23.

215 National Community Action Youth and Drugs "Submission to the Health Committee on the

Psychoactive Substances Bill 2013” at [4].

216 New Zealand Police Association, above n 89, at [3].

217 Danielle Nicholson, above $\mathrm{n} 85$, at 1.

218 Law Commission, above n 92, at 24-25.
} 
... be prohibited except at the point of sale, either within premises where they are sold or supplied [and that] point of sale advertising should be confined to material that communicates objective product information, including the characteristics of the substance, the manner of its production and its price.

Section 56 of the PSA severely limits the ability of a manufacturer, importer or retailer to advertise psychoactive products. Section 56(1) establishes that psychoactive products cannot be advertised via television, radio, any newspaper or publication, nonpsychoactive product-related Internet sites, or any subsequent mediums that may be prescribed through regulations at a later date. ${ }^{219}$

Section 56(3) provides further restrictions in relation to where advertising may occur: ${ }^{220}$

Advertising for an approved product (except a product sold by Internet sale) -

(a) may appear only in premises where the approved product is sold; and

(b) must be confined to the inside of the premises; and

(c) must not be easily visible or audible from outside the premises; and

(d) must be limited to material that communicates objective information about the product, including (without limitation) -

(i) the active ingredients of the product and the appropriate quantity of each active ingredient:

(ii) the price of the product.

Section 56(2) states that a person may not advertise a product in such a way that "particularly appeals" to minors. The restrictions on advertising established under the PSA will reduce the level of exposure to psychoactive products by minors. These restrictions are generally consistent with the Smoke-free Environments Act 1990, which determines that no person may publish a tobacco product advertisement, unless it is to display information such as the price of the product. ${ }^{221}$ In July 2012, the Smoke-free Environments Act was amended to prohibit retailers from placing tobacco products on display in their store, or from trading under a name that indicated they were selling such products. ${ }^{22}$ It has been reported that international research has indicated that "children

\footnotetext{
$219 \quad$ Psychoactive Substances Act, s 56(1).

$220 \quad$ Section 56(3).

$221 \quad$ Smoke-free Environments Act 1990, s 22.

222 Public Health Association "Tobacco display ban will improve New Zealanders' health" (press release, 20 July 2012).
} 
who regularly frequent stores with tobacco displays are twice as likely to take up smoking as those who visit such stores less often". 223

Section 101(1)(b) states:

The Governor-General may, by Order in Council made on the recommendation of the Minister, make regulations for 1 or more of the following purposes...

(b) prescribing restrictions or prohibitions, or both, on the places or premises which approved products may be sold.

It would be worthwhile for the Governor-General to create a regulation which restricts entry into premises dealing in psychoactive products to individuals 18 years old and over. This restriction would limit the exposure of psychoactive products to minors, and consequently, in line with the information available, would also reduce the number of individuals under the age of 18 years old from using such products.

\section{What are the Labelling Restrictions and Requirements for Psychoactive Products?}

The PSA provides strict guidelines as to what may be present on the label of a psychoactive product. Section 58(1) states: ${ }^{224}$

... a label for an approved product must not be designed in a manner or way, or using a medium or form, so as to particularly appeal, or to be likely to particularly appeal, to minors.

The label of a product must also provide the following information: ${ }^{225}$

(a) a list of the active ingredients of the product and the appropriate quantity of each active ingredient; and

(b) the appropriate health warning relating to the product; and

(c) the contact details of the importer, manufacturer, wholesaler, or retailer of the product; and

(d) the telephone number of the National Poisons Centre information service or any other telephone service prescribed in the regulations; and

(e) any other information prescribed by the regulations.

$223 \quad$ Public Health Association, above $\mathrm{n} 219$.

$224 \quad$ Psychoactive Substances Act, s 58(1).

225 Section 58(2). 


\section{1 "The list of active ingredients"}

By requiring that the list of active ingredients are present on the label of a psychoactive product, the PSA affords consumers the ability to perform further research on those ingredients before they make their decision to use such products. Furthermore, if any adverse reactions do occur, medical professionals may be able to react faster to medical emergencies if the ingredients are readily available to them.

\section{2 "Appropriate health warning relating to the product"}

Section 60 requires that an appropriate health warning must be present on all labels of approved psychoactive products. ${ }^{226}$ Section 56(2)(a) also prohibits the use of advertising that promotes the product as being safe. These provisions work together to remove any false sense of security, held by consumers, which suggests that the use of psychoactive products is harmless.

\section{3 "Telephone number of the National Poisons Centre information service"}

The New Zealand National Poisons Centre has submitted that they receive a substantial amount of calls relating to incidents involving psychoactive substances, some from individuals as young as 11 years old. ${ }^{227}$ It is no doubt important that, if approved psychoactive products are to be continually monitored, such support services are contacted about adverse effects caused by approved products. Such notifications will not only enable medical practitioners to help individuals suffering from adverse side effects, but will also allow the Authority to be notified of such adverse reactions to approved products. Consequently, the Authority will be able to make such information available to the public and revoke the approval of a product if necessary. ${ }^{228}$

\section{J Should a Duty to Report Adverse Reactions Exist?}

"Adverse reaction" is defined under the PSA as: ${ }^{229}$

\begin{tabular}{ll}
\hline 226 & Section 60. \\
227 & National Poisons Centre "Submission to the Health Committee on the Psychoactive Substances \\
& Bill 2013" at [5]. \\
228 & Psychoactive Substances Act, s 88. \\
229 & Section 8.
\end{tabular}


(a) an unwanted or harmful reaction experienced by an individual who has used a psychoactive substance or an approved product; and

(b) that is suspected to have arisen from, or be related to the use of the substance or product

The PSA imposes a duty on specified persons to notify the Authority about adverse reactions. Section 98 establishes "a person who holds a licence in respect of the psychoactive substance [and] ... the person who applied for approval of the approved product under s 33" must report any adverse reactions that arise from individual use of a psychoactive substance or a psychoactive product. ${ }^{230}$ This provision is important as it allows the Authority to re-evaluate the risk of harm a product may pose in light of the new evidence. Consequently, re-evaluated products found to pose more than a low risk of harm may be subjected to recall orders in order to remove the threat they pose to individual health and safety.

The Health Select Committee considered whether medical practitioners should also have a responsibility under the Act to report adverse reactions caused by approved psychoactive products. On this question, the Health Select Committee decided that such mandatory reporting was unnecessary as the: ${ }^{231}$

... voluntary reporting of reactions to medicines works well. Rather than including such a requirement in the bill, we recommend that the Ministry of Health work with medical practitioners on a voluntary system of reporting.

The wording of the Act makes it apparent that less faith is placed on licence holders of psychoactive substances and persons applying for approval of psychoactive products. If an offence is committed under s 98, an individual may be subjected to "a term of imprisonment not exceeding 3 months or a fine not exceeding $\$ 500,000$, or both". 232 This penalty for non-compliance is substantial; however, both categories of persons listed under s 98 are financially dependent on the psychoactive substances industry. Consequently, such individuals would be less likely than a medical practitioner to voluntarily report adverse effects caused by their products.

\begin{tabular}{ll}
\hline 230 & Section 98. \\
231 & Psychoactive Substances Bill (100-2) (commentary) at 7. \\
232 & Psychoactive Substances Act, s 98(4).
\end{tabular}




\section{K Does the Ability for the Authority to Recall Approved Products provide a Sufficient Safeguard?}

Section 88 allows the Authority to issue recall orders to the importer, manufacturer, wholesaler, or retailer of an approved product. ${ }^{233}$ Section $88(4)$ limits this ability by providing a definition of recall order which requires that "the Authority has reasonable grounds to believe that the approved product poses more than a low risk of harm to individuals using the product". 234

Section 88 allows the Authority to act on information that may arise after the preclinical and clinical trials of a psychoactive product have been completed. This provision is consistent with the purpose of the Act and allows the Authority to better protect minors, vulnerable individuals, and society in general from the harms that these products may cause.

\section{Is the Appeal System Established under the Psychoactive Substances Act Adequate?}

Section 44 establishes the Psychoactive Substances Appeal Committee (PSAC). ${ }^{235}$ The PSAC must consist of three members, "each appointed by the Minister on any terms and conditions that the Minister thinks fit". ${ }^{236}$ The only restriction on the composition of the PSAC is that one member must be a lawyer with at least seven years legal experience. ${ }^{237}$ The PSA specifies that "in performing its functions or exercising its powers under this Act, the appeals committee must - (a) act independently; and (b) comply with the principles of natural justice". ${ }^{238}$ This system of appeal is consistent with the principle of the Act to regulate psychoactive substances and the requirement that only psychoactive products that pose a low risk of harm should be approved. ${ }^{239}$ The PSAC is the body responsible for ensuring psychoactive products that pose only a low risk of harm are approved. ${ }^{240}$ Furthermore, the PSAC will also ensure such products are not subjected to undue conditions or recall orders. The PSAC is also responsible for reviewing decisions

\begin{tabular}{ll}
\hline 233 & Section 88. \\
234 & Section 88(4). \\
235 & Section 44. \\
236 & Section 44(3). \\
237 & Section 44(4). \\
238 & Section 44(6). \\
239 & Section 4(c). \\
240 & Section 45(2).
\end{tabular}


made by the Authority in relation to licences that have been refused, revoked, subjected to a recall order, or unduly encumbered by conditions. ${ }^{241}$ This provides protection for the psychoactive substances industry, whereby the PSAC can ensure manufacturers and importers of good repute are able to obtain licences.

The system does not allow decisions made by the Authority to be appealed by a thirdparty. The Southern District Health Board recommended that s 45 be expanded to allow: ${ }^{242}$

... individuals or organisations to challenge the decision of the Authority. Thus individuals or organisations that may have particular knowledge about the risk of harm to any individual may provide such information for consideration.

However, the Health Select Committee did "not consider it desirable for third parties to be able to appeal decisions of the regulator". ${ }^{243}$ It appears contrary to the purpose of the Act to prohibit third parties from bringing to the attention of the PSAC evidence that suggests that a product should not have obtained approval, or that a licence should not have been granted. The PSA is already inherently paternalistic, and it would be a justifiable limitation on the autonomy of manufacturers and importers to allow third-party individuals to appeal decisions made by the Authority in order to protect individual and public safety.

\section{How are the Restrictions and Prohibitions on the Importation, Manufacture and Sale of Psychoactive Products Enforced?}

Section 76 provides for the appointment of enforcement officers. This provision has enabled officials to prosecute individuals who have committed offences under the PSA. ${ }^{244}$ In accordance with this objective, s 82 determines that psychoactive substances are subject to forfeiture if they are supplied or possessed in a manner that is considered to be an offence under the Act. ${ }^{245}$ Section 78 also permits any enforcement officer or constable to enter and search retail premises. Recently, a dairy in Hamilton was searched

\footnotetext{
$241 \quad$ Section 45(1).

242 Southern District Health Board "Submission to the Health Committee on the Psychoactive Substances Bill 2013" at [6].

243 Psychoactive Substances Bill (100-2) (commentary) at 4.

244 Fairfax New Zealand News "Hamilton dairy first charged under new drug law" Fairfax NZ News (online ed, New Zealand, 21 August 2013) <http://www.stuff.co.nz>.

245 Psychoactive Substances Act, s 82.
} 
and "charged on one count of selling/supplying a non-approved psychoactive product and a second charge of possession for sale/supply of a non-approved psychoactive product". ${ }^{246}$ The owners of the dairy now may face a fine of up to $\$ 50,000{ }^{247}$ This demonstrates that the provisions under the PSA are being utilised by officials to ensure compliance with the PSA.

\section{N Offences Relating to Psychoactive Substances that are not Approved Products}

Section 70(1) outlines the offences relating to non-approved psychoactive substances under the PSA:

A person commits an offence if the person, without reasonable excuse, -

(a) sells or supplies a psychoactive substance that is not an approved product to any person; or

(b) offers to sell or supply a psychoactive substance that is not an approved product to any person; or

(c) possesses a psychoactive substance that is not an approved product with the intent to sell or supply the psychoactive substance to any person

Section 70(3) also establishes the penalties for this offence:

A person who commits an offence... is liable on conviction -

(a) in the case of an individual, to a term of imprisonment not exceeding 2 years:

(b) in the case of a body corporate, to a fine not exceeding $\$ 500,000$.

The existence of this offence is of fundamental importance to the Act. Non-approved psychoactive substances may potentially pose the greatest risk of harm to individual consumers and society. These psychoactive substances are either substances which have not been considered by the Authority, or alternatively, have been considered by the Authority and deemed to pose more than a low risk of harm. Consequently, it is important to ensure that the penalties provide a sufficient level of deterrence to individuals and body corporates from providing such substances to individual consumers.

\footnotetext{
246 Fairfax New Zealand News, above n 241.

$247 \quad$ Psychoactive Substances Act, s 52.
} 


\section{$O$ Should Personal Possession of a Psychoactive Substance be an Offence under the Psychoactive Substances Act?}

\section{Unlawful possession of unapproved psychoactive substances}

It is an infringement offence, under $\mathrm{s} 71$, for a person to have possession of a psychoactive substance that is not an approved product. ${ }^{248}$ The penalty for this offence is that the individual will be liable on conviction to pay a fine not exceeding $\$ 500$. This will also allow officials to seize unapproved substances from individuals. ${ }^{249}$ However, the Whanganui Community Action Youth and Drugs organisation submitted that: ${ }^{250}$

The [PSA] currently reverses the onus of proof so that the accused would have to prove the product they are carrying is either an approved product; not a "psychoactive substance"; or that they had a reasonable excuse for possessing the substance. The cost of establishing the nature of the substance will fall on them.

This concern is a viable one. Section 72 of the PSA establishes that a constable may serve an infringement notice if he or she "has reasonable grounds to believe... an offence is being... committed". ${ }^{251}$ It is problematic that individuals, who may often be part of a vulnerable population, will have to fund extensive testing on any substances they had on their person to prove their innocence. Because of the extensive costs of testing, it would be reasonable, in relation to the offence of personal possession, to instead impose this onus on the authorities to prove that the substance was an unapproved psychoactive substance.

Furthermore, the Auckland Regional Meththanthetamine Working Group suggested that the offence for personal possession should be removed "provided the person in possession accurately identifies where the product was obtained". ${ }^{252}$ This type of ouster clause for personal possession would allow authorities to better track retailers who are providing and selling unapproved psychoactive products. Consequently, such retailers

\footnotetext{
$248 \quad$ Section 71.

249 Ministry of Health Regulatory Impact Statement: New Regulatory Regime for Psychoactive Substances: Further Policy Decisions (October 2012) at 76.

250 Whanganui Community Action Youth and Drugs Organisation "Submission to the Health Committee on the Psychoactive Substances Bill 2013" at [3].

$251 \quad$ Psychoactive Substances Act, s 72.

252 Auckland Regional Methamphetamine Working Group "Submission to the Health Committee on the Psychoactive Substances Bill 2013" at [3].
} 
could then be charged under the PSA and prohibited from selling any psychoactive products in the future. This alternative would minimise the harm caused to other consumers visiting the same premises in an attempt to obtain unapproved psychoactive products.

This paper suggests that imposing offences on individual consumers should be a last resort. Nevertheless, it also recognises that it is of fundamental importance that authorities are, firstly, able to confiscate such potentially harmful products and, secondly, able to dissuade individuals from using such unapproved products.

\section{Unlawful possession by minors of Psychoactive Products}

Section 48 states "a person under the age of 18 years commits an offence if the person buys or possesses any psychoactive substance, including an approved product". The consequence for this offence is that an individual may be "liable on conviction to a fine not exceeding \$500". This provision addresses the social problem where "children as young as 14 are developing a petty crime habit to pay for their $\$ 500$ a week habit". ${ }^{253}$ These age restrictions exist to protect minors, who are unable to make informed decisions in relation to psychoactive products, from the detrimental effects that may be caused by such products.

Submissions were made to the Health Select Committee which suggested that the existence of an offence for personal possession of psychoactive products by individuals under the age of 18 years old would result in "young people having their future travel and employment options blighted through youthful foolishness". ${ }^{254} \mathrm{Mr}$ McClay responded to this concern by providing assurance that Parliament: ${ }^{255}$

... carefully made sure no one will receive a criminal conviction simply by possessing one of these substances. The worst thing that can happen is an infringement notice similar to a speeding ticket. I am assured by police that even this would be a last resort.

This assertion that only infringement notices will be imposed is reassuring and places less of an encumbrance on individual autonomy than home detention or imprisonment would. Mr McClay has also acknowledged this "will allow police to intervene and prevent harm

\begin{tabular}{ll}
\hline 253 & Brook Sabin, above n 4. \\
254 & (27 June 2013) 691 NZPD 11391. \\
255 & At 11391.
\end{tabular}


to young people and harm from unapproved substances". ${ }^{256}$ Nevertheless, it is problematic to consider that an Act created to protect the vulnerable may in reality inflict further harm.

\section{Conclusion}

The law, in its previous state, allowed unregulated psychoactive substances to cause substantial harm to individual health and society. This paper focussed on three case studies to determine the types of harms such substances may impose. All three case studies demonstrated that psychoactive substances are able to impose severely detrimental harms on individual consumers and society.

This paper then moved to consider the theoretical justifications for the paternalistic nature of the PSA. It concluded that the restrictions created under the PSA were justified. It is necessary for the state to impose limitations on the individual autonomy of consumers and the psychoactive substances industry in order to protect individuals, including minors, from the harms such products may cause, and the risk of substance dependence.

This paper also established that the previous TCDN mechanism, which existed under the MoDA, was insufficient. This system imposed substantial financial costs on the government, allowed significant time delays, and was unable to keep up with the speed in which new psychoactive substances were reaching the public. Having determined that the previous method of controlling psychoactive substances was inadequate; this paper asserted that a new regulatory mechanism, such as the one provided by the PSA, was necessary.

This paper concluded that the PSA was a great initiative and a step forward in the right direction. It was acknowledged in Part VIII that the regulatory scheme under the PSA would benefit from the creation of further restrictions on the autonomy of manufacturers, importers and retailers. Nevertheless, the PSA provides a strong legislative framework that will provide the state a great opportunity to remove the threat previously posed by psychoactive substances in New Zealand. In conclusion, it is proposed that the Act has numerous positive attributes and provides a well-designed safety mechanism that will minimise the risk of harm caused to individuals and society by psychoactive substances. 


\section{BIBLIOGRAPHY}

\section{PRIMARY SOURCES}

\section{A Legislation}

Australia New Zealand Food Standards Code 2000, Standard 2.6.3.

Misuse of Drugs Act 1975.

Natural Health and Supplementary Products Bill 2013 (324-2).

New Zealand Public Health and Disability Act 2000.

Psychoactive Substances Act 2013.

Psychoactive Substances Bill 2013 (100-2).

Sale of Liquor Act 1989.

Smoke-free Environments Act 1990.

\section{B Treaties}

Convention on Psychotropic Substances 19711019 UNTS 175 (opened for signature 11 January 1971, entered into force 16 August 1976).

Single Convention on Narcotic Drugs of 1961529 UNTS 151 (opened for signature 24 January 1961, entered into force 13 December 1964).

United Nations Convention against Illicit Traffic in Narcotic Drugs and Psychotropic Substances 1582 UNTS 95 (opened for signature 20 December 1988, entered into force 11 November 1990).

\section{Parliamentary Materials}

1 Hansard

(9 April 2013) 689 NZPD 9132.

(27 June 2013) 691 NZPD 11390.

(2 July 2013) 691 NZPD 11495.

(9 July 2013) 692 NZPD 11775. 
(11 July 2013) 692 NZPD 12000.

\section{Submissions to Select Committees}

Auckland Regional Methamphetamine Working Group "Submission to the Health Committee on the Psychoactive Substances Bill".

Centre for Addiction Research "Submission to the Health Committee on the Psychoactive Substances Bill”.

National Community Action Youth and Drugs "Submission to the Health Committee on the Psychoactive Substances Bill".

National Poisons Centre "Submission to the Health Committee on the Psychoactive Substances Bill”.

New Zealand Drug Foundation "Submission to the Health Committee on the Psychoactive Substances Bill”.

New Zealand Nurses Association "Submission to the Health Committee on the Psychoactive Substances Bill".

New Zealand Police Association "Submission to the Health Committee on the Psychoactive Substances Bill".

Southern District Health Board "Submission to the Health Committee on the Psychoactive Substances Bill”.

Whanganui Community Action Youth and Drugs Organisation "Submission to the Health Committee on the Psychoactive Substances Bill".

\section{Government Publications}

1 Law Commission Reports

Law Commission Controlling and Regulating Drugs: A Review of the Misuse of Drugs Act 1975 (NZLC R122, 2011).

\section{Papers and Reports}

Business and Economic Research Ltd "Report to Ministry of Health and ACC: Costs of Harmful Alcohol and Other Drug Use" (March 2009) at 69. 
Expert Advisory Committee on Drugs' "Gamma-Hydroxybutyric Acid and Related Substances ('Fantasy')" (December 2001).

Ministry of Health Regulatory Impact Statement: New Regulatory Regime for Psychoactive Substances (1 July 2012).

Ministry of Health Regulatory Impact Statement: New Regulatory Regime for Psychoactive Substances: Further Policy Decisions (October 2012).

Ministry of Health Safety Assessment of Psychoactive Products (01 October 2013)

\section{E International Materials}

International Narcotics Control Board List of Psychotropic Substances under International Control: In accordance with the Convention on Psychotropic Substances of 1971 ( $24^{\text {th }}$ edition, May 2010).

International Narcotics Control Board Red List: List of Precursors and Chemicals Frequently used in the Illicit Manufacture of Narcotic Drugs and Psychotropic Substances under International Control: In accordance with the United Nations Convention against Illicit Traffic in Narcotic Drugs and Psychotropic Substances 1988 $\left(13^{\text {th }}\right.$ edition, January 2012$)$.

International Narcotics Control Board Yellow List: List of Narcotic Drugs under International Control: In accordance with the Single Convention on Narcotic Drugs 1961 $\left(51^{\text {st }}\right.$ ed, December 2012$)$.

The Commission on Narcotic Drugs Promoting the sharing of expertise in and knowledge on forensic drug profiling GA Res 56/5, E/2013/28 (2013).

United Nations Office on Drugs and Crime 2013 World Drug Report Sales No.E.13.XI.6 (2013).

World Health Organisation Neuroscience of Psychoactive Substance Use and Dependence (World Trade Organisation, Switzerland 2004) 


\section{SECONDARY SOURCES}

\section{A Texts}

Adrian Carter, Peter G Miller and Wayne Hall "Ethical Issues in Alcohol, Other Drugs and Addiction-Related Research" John Strang, Peter G Miller and Peter M Miller (ed) Addiction Research Methods (Blackwell Publishing Ltd, United Kingdom, 2010).

"Alcohol-induced liver damage" E Kuntz and H. D. Kuntz (ed) Hepatology: Textbook and Atlas ( $3^{\text {rd }}$ ed, Springer Berlin Heidelberg, 2008).

Andrew M Colman Oxford Dictionary of Psychology (Oxford University Press, New York, 2001).

Collins English Dictionary (11 ${ }^{\text {th }}$ ed, HarperCollins Publishers, Glasgow, 2011).

Douglas Husak and Peter de Marneffe The Legalization of Drugs: For and Against (Cambridge University Press, New York, 2005).

Erwin Kuntz and Hans-Dieter Kuntz "Alcohol-induced liver damage" Hepatology: Textbook and Atlas ( ${ }^{\text {rd }}$ ed, Springer Medizin Verlag Heidelberg, Germany, 2008) 531.

Étienne Dumont (ed) Jeremy Bentham Traités de législation, civile et pénale (1st ed, Bossange, Père et Fils, Paris, 1820) (translated ed: R Hildreth (translator) Jeremy Bentham Theory of Legislation ( $2^{\text {nd }}$ ed, Trübner, London, 1871).

Immanuel Kant Metaphysik der Sitten Paul Natorp (ed) (Reimer, Berlin, 1907) (translated ed: Mary Gregor (Translator) Immanuel Kant The Metaphysics of Morals (Cambridge University Press, Cambridge, 1991)).

John Stuart Mill On Liberty (2 ${ }^{\text {nd }}$ ed, John W Parker and Son, London, 1859).

Ray Corsini The Dictionary of Psychology ( $1^{\text {st }}$ ed, Brunner Routledge, New York, 2002).

Richard Dean "The Formula of Humanity as an End in Itself" Thomas Hill (ed) The Blackwell Guide to Kant's Ethics (Blackwell Publishing Ltd, Oxford, 2009) 83.

Robert E Goodin No Smoking: The Ethical Issues (University of Chicago Press, Chicago, 1989). 
Tom Beauchamp and James Childress Principles of Bioethics $\left(6^{\text {th }}\right.$ ed, Oxford University Press, New York, 2009).

\section{B Journal Articles}

American Dental Education Association "Tobacco use and oral cancer: a global perspective" 65 Journal of Dental Education 328.

Colin Binns, Wan Yun Low and Katie Hewitt "Betel Chewing and Public Health" (2011) 23(6) Asia-Pacific Journal of Public Health 1021.

C Wilkins and others Legal Part Pill Use in New Zealand: Prevalence of use, availability, health harms and 'gateway effects' of benzylpiperazine (BZP) and trifluoromethy lphenylpiperazine (TFMPP) (Centre for Social and Health Outcomes Research and Evaluation, Auckland, 2006).

Deborah L. Zvosec and Others "Case Series of 226 y-hydroxybutyrate - Associated Deaths: Lethal Toxicity and Trauma" (2011) 29(3) American Journal of Emergency Medicine 319

Frank Koopmans and Srdjan Sremac "Addiction and Autonomy: are Addicts Autonomous" (2011) 9 Nova Prisutnost 171.

George F. Koob "Neurobiology of Addiction" (2011) IX the Journal of Lifelong Learning in Psychiatry 55

Gerald Dworkin "Paternalism" (1970) in J Feinberg and H Gross (ed) Philosophy of Law, $4^{\text {th }}$ ed, (1991) 258.

Marc-Antoine Crocq “Historical and cultural aspects of man's relationship with addictive drugs" (2007) 9(4) Dialogues in Clinical Neuroscience 355.

P Yoganathan "Betel Chewing Creeps into the New World" (2002) 98 The New Zealand Dental Journal 40.

Rebecca Walker "Respect for Rational Autonomy" (2009) 19(4) Kennedy Institute of Ethics Journal 339. 
Scott A Norton, "Betel: Consumption and Consequences" (1998) 38(1) Journal of American Academy of Dermatology 81.

Stephen Levine "Parliamentary Democracy in New Zealand" (2004) 57(3) Parliamentary Affairs 646.

Yadhu N Singh "Kava: an old drug in a new world" (2009) 71 Cultural Critique 107.

\section{Other Sources}

\section{Internet Materials}

Graham Gooch and Michael Williams "A Dictionary of Law Enforcement" (2007) Oxford Reference $<\mathrm{http}: / /$ www.oxfordreference.com $>$.

Grant Berghan "Māori point of view" Health Promotion Forum of New Zealand (March 2007) <http://www.hauora.co.nz>.

Mason Durie "Te Whare Tapa Whā" (1985) Ministry of Health <http://www.health. govt.nz>.

Mauri Ora Associates "Best health outcomes for Māori: Practice implications" (December 2008) Medical Council of New Zealand <http://www.mcnz.org.nz>.

Medicines and Healthcare Products Regulatory Agency "My Medicine: Preclinical Research" (25 September 2008) <http://www.mhra.gov.uk>

Medsafe "Conducting Medical Device Clinical Trials in New Zealand" (10 May 2011) $<$ http://www.medsafe.govt.nz>.

Ministry of Health "Interim Licences" (03 October 2013)<http://www.health.govt.nz>.

Ministry of Health "Psychoactive Substances Regulatory Authority: Distribution of Psychoactive Substances and Products in New Zealand" (26 July 2013) <http://www.hea lth.govt.nz>. 
National Institute of Drug Abuse "Drugs, Brains, and Behavior: The Science of Addiction" (2007) <http://www.drugabuse.gov>.

New Zealand Drug Foundation "Inhalants and Solvents" (28 August 2013) $<$ http://www.drugfoundation.org.nz $>$.

Nora Volkow "Bath Salts: Emerging and Dangerous Products" (February 2011) National Institute on Drug Abuse <http://www.drugabuse.gov>

Oxford Dictionaries "Oxford English Dictionary" (2013) <https://oxforddictionaries. com>.

Simon Blackburn "The Oxford Dictionary of Philosophy" (2013) Oxford Reference $<\mathrm{http}: / /$ www.oxfordreference.com>.

Brook Sabin "Dairies becoming 'drug dealers', Parliament hears." (8 May 2013) 3News $<$ http://www.3news.co.nz $>$.

2 Newspaper Articles

Andrew Moran "Bath Salts - Inside the rise of latest drug to capture notoriety" (30 May 2012) Digital Journal $<\mathrm{http}: / /$ digitaljournal.com $>$.

Danielle Nicholson "K2 Victims Clog Hospital Eds" Hamilton News (Hamilton, 21 June 2013).

Fairfax New Zealand News "Hamilton dairy first charged under new drug law" Fairfax NZ News (online ed, New Zealand, 21 August 2013) <http://www.stuff.co.nz $>$.

Fuseworks Media "Authority refuses approval for psychoactive products" Voxy (online ed, New Zealand, 27 September 2013) <http://www.voxy.co.nz>.

Gunraj Sandhu "Drug firms withholding data on bad trials: Dr Wollaston" Top News Arab Emirates (online ed, Abu Dhabi, 24 October 2012) <http://www.topnews.ae $>$. 
Jared Savage "Drug designers stay one step ahead" The New Zealand Herald (Online ed, New Zealand, 10 June 2013) <http:/www.nzherald.co.nz>.

Nicholas Jones "Police warn on tainted E pills" The New Zealand Herald (Online ed, New Zealand, 28 September 2011) <http://www.nzherald.co.nz>.

Rebecca Ryan, “Teen's horrific tangle with legal highs” The New Zealand Herald (online ed, Oamaru, 19 July 2013) <http://www.nzherald.co.nz>.

Science News "Kava Linked to Liver Damage, New Evidence Shows" Science News (online ed, Maryland, 28 February 2008) <http://www.sciencedaily.com>.

Sione Pinomi "Kava restriction puts an unfair burden on Pacific culture" The Sydney Morning Herald (online ed, Sydney, 30 May 2013) < http://www.smh.com.au>.

Susannah Bryan "Even experts question claim that Rudy Eugene was not on bath salts" (6 July 2012) Sun Senteniel <http:/www.sun-sentinel.com/>.

\section{Press Releases}

Peter Dunne "Dunne bans substance found in K2 testing" (press release, 26 November 2012).

Peter Dunne "Dunne: Kava unaffected by Psychoactive Substances Bill” (press release, 11 April 2013).

Peter Dunne "Dunne: Legal highs regime costs and penalties announced" (press release, 10 October 2012).

Peter Dunne "Dunne names Psychoactive Substances Bill expert committee" (press release, 17 May 2013).

Public Health Association "Tobacco display ban will improve New Zealanders' health" (press release, 20 July 2012).

Todd McClay "Psychoactive Substance retailers banned from trading" (press release, 29 September 2013). 
$X$ Appendix One: Abbreviations and Acronyms

DHB District Health Board

BERL Business and Economic Research Ltd

GHB Gamma-Hydroxybutyric Acid

IPSEAC Interim Psychoactive Substances Expert Advisory Committee

MDPV Methylenedioxypyrovalerone

MoDA Misuse of Drugs Act 1975

NHSPB Natural Health and Supplementary Products Bill 2013

NZDF New Zealand Drug Foundation

NZPA New Zealand Police Association

NZPHDA New Zealand Public Health and Disability Act 2000

PSA Psychoactive Substances Act 2013

PSAC Psychoactive Substances Appeal Committee

PSEAC Psychoactive Substances Expert Advisory Committee

TCDN Temporary Class Drug Notices

The Authority Psychoactive Substances Regulatory Authority 